\title{
Applications of environmental DNA (eDNA) in ecology and conservation: opportunities, challenges and prospects
}

Kingsly C. Beng 1 http://orcid.org/0000-0002-0745-7930, Richard T. Corlett

DOI

10.1007/s10531-020-01980-0

Original publication date

9 April 2020 (First Online)

\section{Document version}

Author's accepted manuscript version

\section{Published in}

Biodiversity and Conservation

\section{Citation}

Beng KC, Corlett RT. Applications of environmental DNA (eDNA) in ecology and conservation: opportunities, challenges and prospects. Biodiversity and Conservation. 2020;29(7):2089-121. 

challenges and prospects

3 Kingsly C. Beng ${ }^{1,2^{*}}$; Richard T. Corlett ${ }^{1,2^{*}}$

$4 \quad{ }^{1}$ Center for Integrative Conservation, Xishuangbanna Tropical Botanical Garden, Chinese

5 Academy of Sciences, Menglun, Mengla, Yunnan, 666303, China

$6{ }^{2}$ Center of Conservation Biology, Core Botanical Gardens, Chinese Academy of Sciences,

7 Menglun, Mengla, Yunnan, 666303, China

8 *Corresponding authors: R. T. Corlett (orlett@xtbg.org.cn) K. C. Beng (beng@xtbg.org.cn)

\section{Acknowledgments}

10 This study was financially supported by the Yunnan Oriented Fund for Postdoctoral Researchers

11 (Grant No. Y7YN021B09) and the Chinese Academy Science (CAS) 135 Program (Grant No. 2017XTBG-T03). Neither funding bodies played any role in the design of the study, data collection and analysis, interpretation of results, or writing the manuscript. We are grateful to quality. 


\section{Abstract}

Conserving biodiversity in the face of ever-increasing human pressure is hampered by our lack of basic information on species occurrence, distribution, abundance, habitat requirements, and threats. Obtaining this information requires efficient and sensitive methods capable of detecting and quantifying true occurrence and diversity, including rare, cryptic and elusive species.

Environmental DNA (eDNA) is an emerging technique that can increase our ability to detect and quantify biodiversity, by overcoming some of the challenges of labor-intensive traditional surveys. The application of eDNA in ecology and conservation has grown enormously in recent years, but without a concurrent growth in appreciation of its strengths and limitations. In many situations, eDNA may either not work, or it may work but not provide the information needed. Problems with (1) imperfect detection, (2) abundance quantification, (3) taxonomic assignment, (4) eDNA spatial and temporal dynamics, (5) data analysis and interpretation, and (6) assessing ecological status have all been significant. The technique has often been used without a careful evaluation of the technical challenges and complexities involved, and a determination made that eDNA is the appropriate method for the species or environment of interest. It is therefore important to evaluate the scope and relevance of eDNA-based studies, and to identify critical considerations that need to be taken into account before using the approach. We review and synthesize eDNA studies published to date to highlight the opportunities and limitations of utilizing eDNA in ecology and conservation. We identify potential ways of reducing limitations in eDNA analysis, and demonstrate how eDNA and traditional surveys can complement each other.

Keywords: Biodiversity monitoring, species detection, conservation tools, high-throughput sequencing, traditional surveys, biological invasions 


\section{Introduction}

Quantifying historical and contemporary biodiversity has traditionally relied on morphological and behavioral data collected using direct observations, microscopes, binoculars, traps, and more recently bioacoustics (Basset et al. 2012; Steenweg et al. 2017; Ovaskainen et al. 2018; Burivalova et al. 2019; Khelifa 2019; Rajan et al. 2019; Outhwaite et al. 2020). These techniques are often biased, invasive, destructive, and/or dependent on a declining pool of taxonomic experts for identifying specimens. Traditional surveys are also generally labor intensive and time consuming, and can be inefficient at detecting the true biodiversity present (van der Heyde et al. ; Basset et al. 2012; Gómez-Zurita et al. 2016; Stoeckle et al. 2016; Evans et al. 2017b; Rodriguez-Estrella et al. 2019; Zhang et al. 2020b). The advent of rapid and relatively cheap DNA sequencing techniques has significantly enhanced biodiversity research by overcoming some of the challenges of labor-intensive traditional surveys and offering the opportunity to efficiently characterize biodiversity in time and space, using standardized methods (Corlett 2017; Alexander et al. 2020; Cowart et al. 2020; Ji et al. 2020; Leempoel et al. 2020; Sales et al. 2020; Yang \& Zhang 2020). Among these techniques, environmental DNA (eDNA) sampling has attracted worldwide attention, and interest in using this tool for biodiversity assessment has grown rapidly in the past few years (Figure 1). 


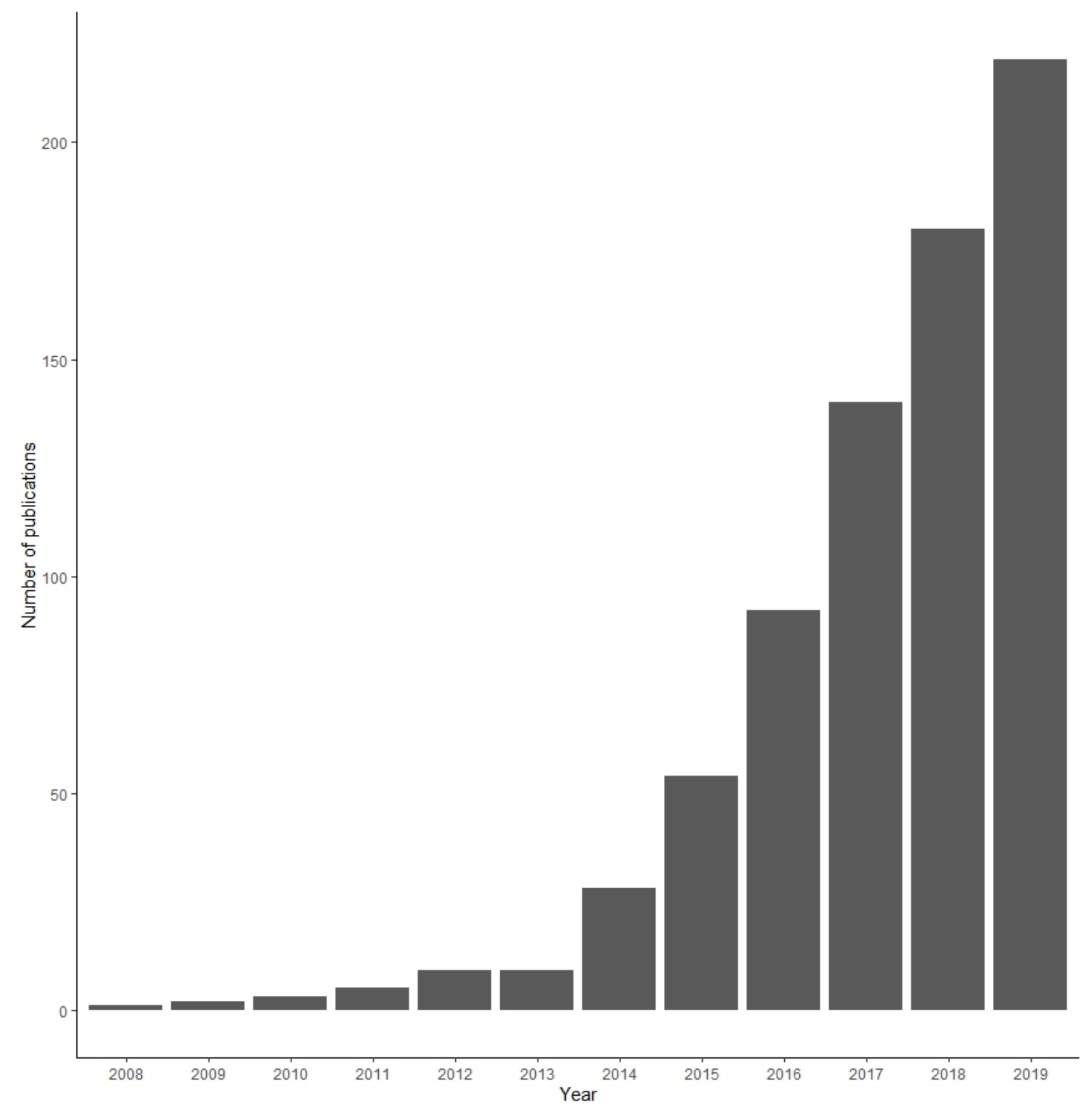

Figure 1 Number of studies using environmental DNA (eDNA) recovered from a literature search with the 60 words 'environmental DNA' OR 'eDNA' for the period between 1 January 2008 and 31 December 2019.

Environmental DNA (eDNA) is genetic material originating from the hair, skin, urine, feces,

63 gametes, or carcasses of organisms that is present, in a more or less degraded form, in water, soil, 
or sediment (TABERLET et al. 2012a; Thomsen \& Willerslev 2015). DNA can persist in the environment for periods from hours in temperate waters, to hundreds or thousands of years in cold, dry permafrost, allowing direct isolation without any other obvious signs of an organism's presence (Thomsen \& Willerslev 2015). The utilization of eDNA has the potential to revolutionize conservation science and practice in several ways. First, eDNA techniques are fast, efficient and relatively cheap, thus providing the opportunity to monitor the dynamics of species, populations and communities, and to map their geographic distribution over long time periods and across large spatial scales (Ficetola et al. 2019; Itakura et al. 2019; Lecaudey et al. 2019; Preissler et al. 2019; Reinhardt et al. 2019; Sutter \& Kinziger 2019; Sales et al. 2020). Second, eDNA sampling is simple, non-destructive, and non-invasive, causing no significant damage to the target species or its habitats (Antognazza et al. 2019b; Mora et al. 2019; Leempoel et al. 2020). Third, eDNA can achieve high detection probabilities for rare, cryptic, and elusive species, even at relatively low densities (Carvalho et al. 2019; Franklin et al. 2019; Shelton et al. 2019; Takahara et al. 2020). Fourth, eDNA enables the early detection of biological invasions and their timely eradication before full establishment (Lin et al. 2019; Nardi et al. 2019; Schumer et al. 2019; Tingley et al. 2019). Fifth, eDNA allows accurate identification of target organisms using standardized, reproducible and auditable criteria that can be applied to different life stages and in different environments (Preissler et al. 2019; Takeuchi et al. 2019a). Sixth, eDNA sampling potentially offers a broad taxonomic breadth, allowing simultaneous biodiversity assessment for a wide range of organisms (Sawaya et al. 2019; Thomsen \& Sigsgaard 2019; Zhang et al. 2020b).

However, despite the ecological and conservation significance of the questions that can potentially be addressed using eDNA, many challenges and limitations exist. eDNA does not always work, and even when it does 'work', the results are not always what are needed. We 
therefore review and synthesize eDNA studies published to date to highlight the opportunities and limitations of utilizing eDNA in ecology and conservation. Additionally, we identify potential routes to addressing fundamental assumptions and reducing the limitations of eDNA (Table 1). We then propose a framework to discuss how eDNA can supplement traditional biodiversity surveys. Lastly, we highlight new areas where eDNA studies are well positioned to advance research in ecology, evolution and biodiversity.

\section{Literature search}

We searched for peer-reviewed journal papers in the Web of Science using the keywords 'environmental DNA' and 'eDNA', and restricted the review to studies involving macroorganisms. The final literature search was conducted on 16th January 2020 and covered the period between 1 January 2008 and 31 December 2019 (2008 representing the year when eDNA emerged as a survey tool in macro-ecology; (Ficetola et al. 2008)).

\section{Current ecological and conservation questions addressed using eDNA}

Two broad approaches that have received the most attention in eDNA-based studies are barcoding and metabarcoding. The main difference between barcoding and metabarcoding is that barcoding uses species-specific primers to detect the DNA fragments of a single species within an environmental sample (Takahara et al. ; Franklin et al. 2019; Strickland \& Roberts 2019; Akamatsu et al. 2020; Harper et al. 2020; Kessler et al. 2020; Togaki et al. 2020) while metabarcoding uses universal primers to simultaneously detect millions of DNA fragments from the widest possible range of species from multiple trophic levels and domains of life (Alexander et al. 2020; Cowart et al. 2020; Djurhuus et al. 2020; Yang \& Zhang 2020; Zhang et al. 2020b). For eDNA barcoding, conventional PCR (cPCR) is used to detect the presence of a species 
(Jerde et al. 2011a; Dejean et al. 2012; Thomsen et al. 2012c; Mahon et al. 2013; Piaggio et al. 2014; Fukumoto et al. 2015) and quantitative PCR (qPCR) is used to quantifying the relative abundance of DNA sequences (proxies for relative species abundance or biomass) or to improve the sensitivity of species detection (Takahara et al. 2012; Goldberg et al. 2013; Pilliod et al. 2013; Doi et al. 2015; Klymus et al. 2015; Laramie et al. 2015; Balasingham et al. 2017). eDNA barcoding has been particularly useful for detecting invasive, rare, and cryptic species, even in difficult to access habitats, map their distributions, and design management strategies (Levi et al. 2019) (Levi et al. 2019; Qu \& Stewart 2019; Reinhardt et al. 2019b). eDNA metabarcoding has been successfully used to characterize past and present biodiversity patterns (Edwards et al. 2018; Singer et al. 2018; Zinger et al. 2019), to understand trophic interactions and dietary preferences (Galan et al. 2018; Harrer \& Levi 2018; Mora et al. 2019; Thomsen \& Sigsgaard 2019), to study the spawning ecology of elusive species (Maruyama et al. 2018; Antognazza et al. 2019; Bracken et al. 2019; Takeuchi et al. 2019b), and to monitor ecosystem health and dynamics (Cordier et al. 2019; Evrard et al. 2019; Graham et al. 2019).

\section{Detecting rare, cryptic or endangered species}

Detection and monitoring of rare, cryptic, and endangered species using conventional techniques is a difficult task that often involves huge amounts of time and effort (Qu \& Stewart 2019b). Repeated sampling (in space and time) with conventional surveys is expensive and can cause irreparable damage to the target organism or its habitat. eDNA analysis offers a cost-efficient approach to non-invasive monitoring of such species. Several studies have evaluated the methodological efficiency of eDNA versus conventional surveys in detecting rare, cryptic, and endangered species, and demonstrated that the probability of eDNA accurately detecting a target species is relatively higher than or comparable to that of conventional surveys (Deiner et al. 
2017). However, most eDNA-based studies have focused on aquatic taxa, especially fishes and amphibians (Beauclerc et al. 2019; Deutschmann et al. 2019). Studies on other taxa and in terrestrial environments are scarce.

\subsection{Estimating species distribution}

Although there is increasing global concern about declines in populations of wildlife (Jia et al. 2018; Saha et al. 2018; Sekercioglu et al. 2019), monitoring the population dynamics of some species remains a challenge, partly due to large uncertainties in their geographic distributions, limited understanding of their lifestyles, the complexity of their life histories, and methodological constraints (Riggio et al. 2018; Srinivasan 2019; Wineland et al. 2019). eDNA analyses have enhanced the monitoring of wildlife species distribution and abundance over large spatial and temporal scales using efficient, sensitive and standardized methods (Matter et al. 2018; Hobbs et al. 2019; Itakura et al. 2019).

\subsection{Biomonitoring ecosystem health and dynamics}

Biological invasions, pests, and diseases constitute one of the most serious threats for global biodiversity and cause adverse environmental, economic and public health impacts (Sengupta et al. 2019; Tingley et al. 2019; Walsh et al. 2019). There is thus an urgent need to develop effective monitoring and management strategies to contain the spread and establishment of these harmful biological agents (Marshall \& Stepien 2019; Orzechowski et al. 2019). However, such efforts are constrained by our limited capacity to efficiently detect biological threats, especially when these harmful agents are at low density (Manfrin et al. 2019). eDNA has proven to be a very effective and sensitive sampling method, capable of monitoring the spread and establishment of harmful biological agents through early detection, analysis of spread patterns, 
and evaluation of population dynamics (Amberg et al. 2019; Ardura 2019; Fernanda Nardi et al. 2019; Gomes et al. 2019; Rudko et al. 2019).

\subsection{Diet and trophic interactions}

Understanding and quantifying biotic interactions, such as predator-prey and host-parasite relationships, are key components of ecological research. However, these important biological processes remain poorly investigated, primarily due to methodological challenges. eDNA is increasingly being used in diet analysis to estimate diversity, composition and occurrence frequency of prey items in predator feces (Galan et al. 2018; Jusino et al. 2019; Mata et al. 2019; Mora et al. 2019). DNA deposited by pollinators on flowers, and by dispersers on seeds, also offers an opportunity to investigate plant-animal interactions and the role of these interactions in the maintenance of ecosystem functions and the provision of ecosystem services (Harrer \& Levi 2018; Thomsen \& Sigsgaard 2019).

\subsection{Spawning ecology}

Most aquatic animals, except for aquatic mammals and reptiles, reproduce through the process of spawning. Identifying areas for spawning, as well as the spatial extent of spawning activities, is vital for the effective management and conservation of these species. However, understanding the natural reproductive ecology of these organisms have mostly relied on collections of eggs, larvae and spawning-condition adults (Tsukamoto et al. 2011; Antognazza et al. 2019b). These techniques are often biased, invasive, destructive, and/or strictly dependent on a declining pool of taxonomic experts for identifying life history stages (Maruyama et al. 2018). Surveys of this nature are also generally labor intensive and time consuming, and can be inefficient at detecting certain life history stages (Antognazza et al. 2019b; Fritts et al. 2019). For instance, kick- 
sampling for eggs is sometimes conducted in areas of relatively shallow waters or during the day whereas the adults spawn in deep waters or at night (Antognazza et al. 2019a). eDNA enables the detection of a species regardless of its life stage or gender, and is transforming our ability to non-invasively quantify spawning activities, and identify the spatial extent of spawning, with limited resources (Maruyama et al. 2018; Tillotson et al. 2018; Antognazza et al. 2019b; Bracken et al. 2019; Fritts et al. 2019; Takeuchi et al. 2019b; Takeuchi et al. 2019c).

\subsection{Monitoring biodiversity}

Conserving biodiversity in the face of ever-increasing human pressure is hampered by our lack of basic information on past and present species occurrences, distributions, abundances, habitat requirements, and threats. Obtaining this information requires efficient and sensitive sampling methods capable of detecting and quantifying true biodiversity, especially in megadiverse regions with many cryptic and undescribed species (Kuzmina et al. 2018; Lacoursière-Roussel et al. 2018). eDNA has increased our ability to monitor past and present biodiversity, by overcoming some of the challenges of labor-intensive traditional surveys (Edwards et al. 2018; Fraser et al. 2018; Montagna et al. 2018; Cilleros et al. 2019). It is now possible and costefficient to assess the biodiversity of entire communities and infer diversity and assemblage patterns for a wide range of taxonomic groups simultaneously (DiBattista et al. 2019; Zinger et al. 2019).

\section{Challenges and limitations of eDNA}

The application of eDNA in ecology and conservation has grown enormously in recent years, but without a concurrent growth in appreciation of its limitations. While there is evidence that eDNA can increase the precision and resolution obtainable from traditional biodiversity surveys 
(Thomsen \& Willerslev 2015; Yamamoto et al. 2017), this is certainly not true in all circumstances, even with standardized and highly sensitive assays (Hinlo et al. 2017; Ulibarri et al. 2017). In cases where eDNA has been successful, it might not necessarily be the appropriate tool if information is required on the abundance or biomass of species (although this may be possible in some cases (Takahara et al. 2012; Pilliod et al. 2013; Doi et al. 2015; Baldigo et al. 2017)), its ecology (life-history, sex ratio, breeding status), or its conservation status (Evans et al. 2017b; Trebitz et al. 2017). Presence/absence information from eDNA is useful in conservation for monitoring populations at large spatial scales and for identifying habitats that are of high value to species of conservation concern (Voros et al. 2017; Weltz et al. 2017). eDNA can also be used to detect the first occurrence of an invasive species or the continued presence of a native species that was considered extinct, sometimes at relatively low densities (Stoeckle et al. 2017; Trebitz et al. 2017). However, presence/absence can be misleading when eDNA is present in the environment in the absence of living target organisms or when eDNA is not detected but the target organism is present (Song et al. 2017). Abundance data provide far more information on the status of a population than presence/absence data and thus potentially allow for more robust assessments of the factors affecting populations.

To date, increased speed and reduced cost remain the key advantages of eDNA (Sigsgaard et al. 2015b). Whether eDNA sampling is more sensitive and has higher resolution than traditional surveys remain controversial. For some species or taxa, eDNA performs better than traditional methods (Kraaijeveld et al. 2015; Deiner et al. 2016; Olds et al. 2016; Strickland \& Roberts 2019; Tingley et al. 2019), for others, eDNA is as good as traditional surveys (Hanfling et al. 2016; Hopken et al. 2016; Yamamoto et al. 2017), while for some, eDNA provide little additional benefit to surveillance (Rose et al. 2019; Walsh et al. 2019; Wood et al. 
2019). However, studies in which eDNA has been unsuccessful are much less likely to be published, so we inevitably know less about eDNA's failures than its successes. In addition to the taxa- or species-specific differences in sensitivity between eDNA and traditional surveys, the environment, time of the year, and biotic factors also play important roles (Dejean et al. 2011; Pilliod et al. 2014; Barnes \& Turner 2016; O'Donnell et al. 2017; Lacoursière-Roussel et al. 2018; Anglès d'Auriac et al. 2019; Takeuchi et al. 2019a). In aquatic ecosystems, for example, eDNA can persist from a few hours to a month after release (Dejean et al. 2011; Pilliod et al. 2014). In addition, differences in eDNA persistence can occur even within the same environment, for example, between the surface and bottom layers of a water body (O'Donnell et al. 2017; Lacoursière-Roussel et al. 2018; Anglès d'Auriac et al. 2019).

Studies that have quantitatively assessed the cost-efficiency of eDNA relative to traditional methods suggest that eDNA sampling is relatively cheaper than traditional surveys (Biggs et al. 2015; Davy et al. 2015; Huver et al. 2015; Sigsgaard et al. 2015a; Qu \& Stewart 2019a), although this can depend on the target taxa, site-specific detection rates, budgets, and other considerations (Smart et al. 2016). For instance, Qu \& Stewart (2019) found that the cost of detecting and quantifying Yangtze finless porpoise (Neophocaena asiaeorientalis asiaeorientalis) populations using visual surveys was 1.41-1.88 times (monthly cost) and 4.22-5.64 times (seasonal cost) higher than using eDNA. Sigsgaard et al. (2015) found that using eDNA (\$4250) to detect the European weather loach (Misgurnus fossilis) was 1.9 times cheaper than using a combination of traditional methods (\$8100). Biggs et al. (2015) found that the cost of detecting newts (Triturus cristatus) was 10.4 times cheaper using eDNA ( $€ 140$ per site) compared to traditional field sampling ( $€ 1450$ per site). Davy et al. 2015 found that the cost of detecting nine sympatric freshwater turtles using traditional surveys was 2-10 times higher than using eDNA. 
However, (Smart et al. 2016) evaluated the relative cost of eDNA and bottle-trapping for detecting the European newt (Lissotriton vulgaris vulgaris) and found that eDNA sampling was more cost-efficient than trapping under low setup costs but bottle-trapping was more cost-efficient than eDNA under high setup costs.

Qualitatively novel applications with actual conservation outcomes are still largely lacking, although researchers are now moving away from proof-of-concept research to studies that quantify population dynamics across organisms and environments (Stewart et al. 2017; Carraro et al. 2018). However, the ability of eDNA to detect the continuous presence of a species not sighted in its habitat for many years also raises questions about the mechanisms and processes by which eDNA is transported and the conservation implications of unexplained variability in eDNA transport (Sigsgaard et al. 2015a; Jerde et al. 2016; Lim et al. 2016). Although methods and models to handle imperfect detection are increasingly being improved (Piggott 2016; Guillera-Arroita et al. 2017; Ji et al. 2019), it is not possible to simply ignore the presence of eDNA in the absence of living target organisms and/or the absence of eDNA in the presence of living target organisms without actual field surveys. Increased PCR replication can maximize eDNA detection and minimize false positives and/or negatives (Piggott 2016) but this cannot substitute for actual biological replicates and will increase cost (Ficetola et al. 2015; Roussel et al. 2015; Evans et al. 2017b). Detection of species using eDNA relies on DNA isolated from living and dead cells (characterized by low concentration and high degradation (Deagle et al. 2006)), and on PCR amplification (subjected to high variability and stochasticity (Kebschull \& Zador 2015)), and is prone to imperfect detection (Pilliod et al. 2014; Ficetola et al. 2015). Increasing the number of DNA extracts per sample or the number of amplifications per DNA extract does not necessarily increase the probability of detection but will require more 
laboratory reagents, time, and effort. However, collecting biological samples from sites where the target species is most likely to be detected—-based on knowledge of the target species' ecology — can enhance the detection probability (Ficetola et al. 2015; Akre et al. 2019; Wineland et al. 2019; Wood et al. 2019; Bedwell \& Goldberg 2020; Vimercati et al. 2020).

Degradation of eDNA in the environment limits the scope of eDNA studies, as often only small segments of genetic material remain, particularly in warm, humid conditions (Strickler et al. 2015; Collins et al. 2018; Goldberg et al. 2018; Harrison et al. 2019; Moushomi et al. 2019; Murakami et al. 2019; Sirois \& Buckley 2019). Additionally, the impacts of varying environmental conditions on time to degradation and the potential of DNA to travel throughout media such as water can affect inferences of fine-scale spatiotemporal trends in species and communities (Coissac et al., 2012; Taberlet et al., 2012a; Eichmiller et al., 2016; Goldberg et al., 2016; Deiner et al., 2017; Hering et al., 2018)(Hering et al. 2018). However, eDNA workflows have been improving continuously, including the optimization of protocols for improved sample collection and preservation, library preparation, sequencing, and bioinformatics (Williams et al. 2016; Yamanaka et al. 2017; Ji et al. 2019; Jusino et al. 2019; Koziol et al. 2019; Muha et al. 2019; Singer et al. 2019; Thomas et al. 2019; Yamahara et al. 2019). For instance, Thomas et al (2019) developed desiccating filter housings that can automatically preserve captured eDNA via desiccation. These housings also reduce the amount of time (or steps) required to handle samples, and do not require the addition of chemicals and/or cold storage, thus minimizing the risk of contamination. Singer et al (2019) found that for the same eDNA sample, Illumina NovaSeq detected $40 \%$ more metazoan families than MiSeq and attributed this difference to NovaSeq's advanced technology. 

analysis, and detection of rare or invasive species, we are concerned that it is being over-

291

292 promoted as a standalone technique for ecological and conservation initiatives that may not fully benefit from it (Roussel et al. 2015). We emphasize, in particular, that it is challenging to distinguish between detection of eDNA and detection of a species, or to quantify organismal abundance and biomass using eDNA, without a clear understanding of the challenges and limitations of the technique. Failure to address these problems may confound the interpretation of eDNA data.

\subsection{Imperfect sampling of eDNA and false detection}

eDNA is prone to imperfect sampling and false detection, which can occur at various stages of the project, including field collection, sample storage, molecular analysis, and bioinformatics workflows (Ficetola et al. 2016; Deiner et al. 2017; Doi et al. 2019; Piñol et al. 2019). Cases where eDNA is detected in the environment in the absence of target organisms (false positives, (Ficetola et al. 2015; Ficetola et al. 2016; Lahoz-Monfort et al. 2016; Stoeckle et al. 2016; Guillera-Arroita et al. 2017)) or where eDNA is not detected but the target organism is present (false negatives, (Morin et al. 2001; Ficetola et al. 2008; Schmidt et al. 2013; Ficetola et al. 2015; Willoughby et al. 2016; Doi et al. 2019)) are common. Although site occupancy models have been proposed as a way to account for imperfect detection, they largely depend on the number of replicate samples per site and on the number of replicate amplifications per DNA sample (PCR), which vary considerably across taxa (Schmidt et al. 2013; Matter et al. 2018; Chen \& Ficetola 2019; Doi et al. 2019; Strickland \& Roberts 2019). Causes of false detections include

\section{i. Limited persistence of eDNA in the environment}


A key motivation for using eDNA is the fact that all organisms shed DNA into their environment, allowing direct isolation without any obvious signs of the organism's presence (TABERLET et al. 2012a). However, DNA released by aquatic or terrestrial organisms is not necessarily concentrated at the site of its release, but is transported across space and degraded over time (Deiner \& Altermatt 2014a; Jane et al. 2015; Sansom \& Sassoubre 2017; Rice et al. 2018; Murakami et al. 2019). The eDNA release and decay rates depend on several biotic (e.g. lifehistory traits, species interactions, microbes) and abiotic (e.g. UV radiation, temperature, salinity) factors (Pilliod et al. 2014; Klymus et al. 2015; Lacoursière-Roussel et al. 2016; Stewart 2019). Our current understanding of how eDNA persist under different environmental conditions for different species is limited, but this information is critical for deciding on the most appropriate time window to conduct eDNA surveys. Environmental conditions are constantly changing and can be different in each location throughout the year. For example, Pilliod et al. 2014 detected eDNA after 11 and 18 days in water samples that were stored in the dark but eDNA was no longer detectable in samples that were exposed to full-sun after 8 days. Temperature directly affects the metabolic rate of some organisms (e.g. amphibians, invertebrates, reptiles, and fish) and consequently could strongly affect eDNA release rate (Clarke \& Fraser 2004; LacoursièreRoussel et al. 2016). For instance, Lacoursière-Roussel et al. 2016 showed that fish released more eDNA in warm water $\left(14^{\circ} \mathrm{C}\right)$ than in cold water $\left(7^{\circ} \mathrm{C}\right)$ and that the relationships between eDNA concentration and fish abundance or biomass were stronger in warm water than in cold water.

\section{ii. Primer biases}

The suite of molecular markers used in eDNA analysis is extremely important for the identification of species in both single taxa and multi-species samples. However, successful 
amplification of eDNA depends highly on primer specificity, sensitivity, and efficiency (Stadhouders et al. 2010; Nichols et al. 2018). eDNA samples are characterized by highly heterogeneous DNA from mixtures of many different taxa or haplotypes, making it difficult to achieve full complementarity between primers and target sequences during PCR (Stadhouders et al. 2010; Nichols et al. 2018; Wei et al. 2018). These primer-template mismatches can affect both the stability of the primer-template duplex and the efficiency with which the polymerase extends the primer, potentially leading to biased results or complete PCR failure (Stadhouders et al. 2010). For instance, primer bias may lead to the preferential amplification of abundant sequences compared to rare ones, or of shorter fragments compared to longer ones, or of nontarget organisms compared to target organisms (Nichols et al. 2018; Xia et al. 2018). Unlike metabarcoding, primer bias is not a major issue for barcoding. However, targeted PCR-based amplification of samples using species-specific primers, instead of universal primers, should be strongly encouraged in eDNA barcoding (Wilcox et al. 2013; Davy et al. 2015; Cannon et al. 2016). Conventional PCR (cPCR) methods may cross-amplify and provide false positive results but quantitative PCR (qPCR) methods are likely to be more sensitive (Wilcox et al. 2013).

\section{iii. Inhibition of DNA amplification}

eDNA analysis involves the collection of complex and heterogeneous mixtures from aquatic ecosystems, soils, sediments, or feces (Koziol et al. 2019). The polymerase chain reaction (PCR) is the standard method for detection and characterization of organisms and genetic markers in these sample types. However, PCR is vulnerable to inhibitors, which are usually present in eDNA samples and which may affect the sensitivity of the assay or even lead to false negative results (Schrader et al. 2012; Nichols et al. 2018; Hunter et al. 2019). PCR inhibitors represent a diverse group of substances including bile salts from feces, polysaccharides from plant materials, 
collagen from tissues, heme from blood, humic acid from soil, urea from urine, and melanin and eumelanin from hair and skin (Watson \& Blackwell 2000; Radstrom et al. 2004; Schrader et al. 2012). Although PCR inhibitors have different properties and mechanisms of action, they generally exert their effects through direct interaction with DNA or interference with thermostable DNA polymerases (Schrader et al. 2012). Direct binding of inhibitors to DNA can prevent amplification and facilitate co-purification of inhibitor and DNA (Schrader et al. 2012; Jane et al. 2015). Inhibitors can also interact directly with a DNA polymerase to block enzyme activity. Since some inhibitors are predominantly found in specific types of samples, matrix-specific protocols for preparation of nucleic acids before PCR are essential (Schrader et al. 2012; Hunter et al. 2019).

\section{iv. Sample contamination}

Contamination occurs when DNA from an outside source (exogenous DNA) gets mixed with DNA relevant to the research. For instance, if a frog is eaten at one pond, then the predator defecates at another, this may introduce the frog's DNA to a pond where the frog is not present. Because of the sensitivity of the technique, this is a serious issue in eDNA surveys and may result in false positive detections and subsequent misinterpretation of results (Goldberg et al. 2016; Wilson et al. 2016). eDNA analysis requires multiple steps of sample handling and manipulation in the field (collection, storage and transportation) and in the lab (storage, DNA extraction, amplification, library preparation and sequencing), so contamination may occur at various stages of the research (Goldberg et al. 2016; Doi et al. 2017). In the field, contamination may occur when DNA from one or multiple samples is unintentionally transferred into another sample, either from another site in the same study or from an unknown locality. This usually occurs when the same field equipment (e.g. corers, filters, gloves) is used repeatedly for 
sampling different sites without thorough treatment (e.g. sterilization). In the lab, contamination may occur when remnant DNA from previous molecular experiments (e.g. DNA extraction, amplification, library preparation and sequencing) spreads into new samples or when the same lab equipment (e.g. tubes, pipettes, benchtops) is repeatedly used for conducting different experiments without thorough decontamination. Instead of standard autoclaving (Unnithan et al. 2014) or the commonly used $10 \%$ bleach (sodium hypochlorite) solution (Prince \& Andrus 1992), treatment of field and lab equipment with $50 \%$ bleach solution and thorough rinsing can effectively destroy and remove unwanted DNA and PCR products (Kemp \& Smith 2005; Champlot et al. 2010; Goldberg et al. 2016; Wilcox et al. 2016).

\section{v. eDNA from dead individuals}

Both dead and live organisms release DNA into the environment and both contribute to the eDNA pool. For most purposes, the researcher is only interested in the former - DNA from live organisms - but distinguishing between them remains a challenge. Since DNA degrades with time, the longer DNA fragments in a particular environment are likely to represent the most recent DNA. (Jo et al. 2017) compared changes in copy numbers of long (719 bp) and short (127 bp) eDNA fragments with time and suggested that the concentration of longer eDNA fragments reflects fish biomass more accurately once the effects of decomposition and contamination have been removed. However, removal of carcasses and avoidance of contamination in natural settings is almost impossible, given that birth and mortality are key processes in the dynamics of natural populations. The contribution of dead organisms to the eDNA pool can vary considerably in different environments. For instance, in the tropics and subtropics with relatively higher temperatures and faster degradation rates, carcasses do not persist 
long. (Tsuji et al. 2017) found that ayu sweetfish (Plecoglossus altivelis altivelis) and common carp (Cyprinus carpio) eDNA degradation rates increased with increasing water temperatures.

\section{vi. Ancient DNA (aDNA) resuspension}

Environmental DNA may occur as particle-bound or free-living dissolved molecules (Turner et al. 2014a). Particles that bind DNA may settle over long periods and be resuspended through natural phenomena like erosion, turbulence caused by fast-flow hydrological events, wind, and wave action or bioturbation. In cases where the objective is to detect the continued presence of a native species that was considered extinct, aDNA resuspension can lead to false positive results and misinform management.

\subsection{Difficulties in quantifying abundance and biomass}

One of the most important issues limiting the application of eDNA in environmental monitoring is the difficulty of quantifying species abundance and biomass. To date, results of most eDNA studies have been interpreted as presence/absence (occurrence) information. However, some studies have used mock communities with known and differing assemblage structures or combined conventional surveys with eDNA in order to explore whether or not eDNA can provide quantitative information (Piñol et al. 2019). The outcomes of these studies are still fairly contentious, with strong, weak, and no quantitative estimates reported (Piñol et al. 2019). For instance, (Pilliod et al. 2013) reported that eDNA concentrations of Rocky Mountain tailed frogs (Ascaphus montanus) and Idaho giant salamanders (Dicamptodon aterrimus) were positively associated with in-stream density, biomass, and proportion of area occupied by the two species. (Takahara et al. 2012) showed that eDNA concentration in water samples correlated with the biomass of common carp (Cyprinus carpio) in artificial ponds, and (Thomsen et al. 2012c) 
showed that eDNA concentration was correlated with the density of common spadefoot toads (Pelobates fuscus) and great crested newts (Triturus cristatus) in natural ponds. (Evans et al. 2016) found a modest, but positive relationship between species abundance and sequencing read abundance for eight fish and one amphibian species in replicated mesocosms, while (Deagle et al. 2013) reported that the proportions of fish sequences recovered from 39 seal scats did not match the proportions of the three fish species the seals consumed.

\subsubsection{Problems with interpreting relative abundance data generated from PCR-based techniques and metabarcoding loci}

\section{i. Variability in eDNA deposition and preservation}

The production and stability of eDNA (origin, state, decay, transport, persistence (Barnes \& Turner 2016)) vary greatly among taxa, individuals, and even tissues within the same organism.

The concentration of DNA in the environment is influenced by several complex processes, including movement and degradation, making it difficult to extract abundance information from eDNA signals. Furthermore, an organism's size, age, condition, or biological activity can influence the relationship between eDNA concentration and relative abundance (Spear et al. 2015; de Souza et al. 2016; Erickson et al. 2016; Stewart et al. 2017), interactions between a target species and closely or distantly related species can influence the amount of eDNA released (Sassoubre et al. 2016), and environmental conditions can influence eDNA release, persistence, degradation, transport, location, and settlement (Laramie et al. 2015; Erickson et al. 2016; Stewart et al. 2017). For instance, large-bodied, long-lived, year-round, and highly dispersed species are more likely to be detected using eDNA than small-bodied, short-lived, seasonal, and 
sedentary species (ANDERSEN et al. 2012a; Buxton et al. 2017; Dunn et al. 2017; Hemery et al. 2017; Rees et al. 2017; Nichols et al. 2018).

\section{ii. eDNA sampling and processing biases}

Key considerations in eDNA analysis are maximizing DNA capture in the field, minimizing degradation during transport and storage, and successful isolation and amplification (Pilliod et al. 2013, 2014; Turner et al. 2014b; Renshaw et al. 2015a; Goldberg et al. 2016; Wood et al. 2019).

The choice of eDNA sampling and processing protocols can significantly influence DNA yield, detection probability, and the resulting abundance and biodiversity estimates (Brannock \& Halanych 2015; Deiner et al. 2015b; Renshaw et al. 2015a; Djurhuus et al. 2017; Thomas et al. 2018). Specific protocols used in each study vary with sample type (water, feces, soil, sediment), the ecosystem of interest (freshwater, marine, terrestrial), and the questions being investigated (Renshaw et al. 2015a; Goldberg et al. 2016; Djurhuus et al. 2017). For diet analysis, individual fecal samples are collected and dehydrated immediately using either alcohol or silica gel or a combination of both (Deagle et al. 2009; Zeale et al. 2011; Galan et al. 2012; Pompanon et al. 2012; Clare et al. 2014; Mata et al. 2016). In terrestrial ecosystems, multiple soil cores are collected and analyzed separately or are pooled together, homogenized and a representative subsample is taken. DNA is extracted from the soil samples immediately after collection or samples are stored at $-20{ }^{\circ} \mathrm{C}$ or $-80{ }^{\circ} \mathrm{C}$ for processing at a later date (van der Heyde et al. ; Andersen et al. 2012b; Bienert et al. 2012; Epp et al. 2012; Taberlet et al. 2012b; Yoccoz et al. 2012). In aquatic ecosystems, different protocols are being used to collect water, capture eDNA with filters, transport samples from the field, and to store water and/or filters prior to DNA extraction and amplification (Goldberg et al. 2011; Pilliod et al. 2013; Biggs et al. 2015; Renshaw et al. 2015a; Majaneva et al. 2018). Some studies filter, precipitate or centrifuge water 
on-site, and preservation media (e.g. ice, sodium acetate, lysis buffers, and absolute ethanol) are used to stabilize eDNA for enough time (up to $24 \mathrm{~h}$ ) to safely transport it for storage and processing (Ficetola et al. 2008; Goldberg et al. 2011; Pilliod et al. 2013; Biggs et al. 2015; Valentini et al. 2016a). In other studies, water is transported in cold conditions and filtration or precipitation is done in the laboratory (Jerde et al. 2011b; Thomsen et al. 2012c; Goldberg et al. 2013). Minimizing DNA degradation in these samples is challenging, especially in remote field sites with little or no access to cooling and in situations where samples need to be transported for several days (e.g. international flights with stop overs) before processing.

Various types of filters have been used to capture eDNA (Minamoto et al. 2012; Thomsen et al. 2012a; Goldberg et al. 2013; Jerde et al. 2013; Piaggio et al. 2014) and the efficiency of each filter type depends on its pore size, the volume and chemical properties (e.g. pH, organic and inorganic particles) of the water filtered, and the extraction method (Liang \& Keeley 2013b; Turner et al. 2014a; Renshaw et al. 2015a; Eichmiller et al. 2016; Djurhuus et al. 2017; Majaneva et al. 2018). In general, filtration is relatively more efficient for eDNA capture than precipitation and centrifugation methods (Deiner et al. 2015a; Renshaw et al. 2015b; Eichmiller et al. 2016; Spens et al. 2017; Majaneva et al. 2018). Among filters, cellulose nitrate (CN) filters capture relatively more eDNA than polyethene sulfone (PES), polyvinylidene fluoride (PVDF), and polycarbonate (PC) filters, while glass microfiber (GMF) filters capture relatively more eDNA than PC filters (Liang \& Keeley 2013a; Eichmiller et al. 2016).

In some aquatic environments (e.g. muddy water), the pore size of a filter can influence filtration rate, where larger pore size filters (e.g. $5 \mu \mathrm{m}$ ) or pre-filtration require less time than smaller pore size filters $(1 \mu \mathrm{m})$. However, larger pore size filters and pre-filtration are less efficient in DNA recovery than smaller pore size filters (Liang \& Keeley 2013a; Eichmiller et al. 2016). 
492

493

494

495

496

497

498

499

500

501

502

503

504

505

506

507

508

509

510

511

512

513

eDNA species detection and quantification is usually accomplished using relatively short DNA fragments. These increase detection probabilities with highly degraded eDNA, but they are prone to high error rates and biases. Primers used to amplify these short DNA fragments may not perfectly match the target organism's DNA, leading to primer-template mismatches and differential amplification of target DNA (Leray et al. 2013; Elbrecht \& Leese 2015; Bista et al. 2018). Primers can fail to detect low concentrations of eDNA, miss entire taxa or preferentially amplify the eDNA of non-target organisms. For example, short DNA fragments are more likely to represent ancient DNA (aDNA) that has persisted in the environment for very long periods, bound to sediments, and represent historical biodiversity (Barnes et al. 2014; Barnes \& Turner 2016). On the other hand, longer DNA fragments may represent more recent biological information, but are present at lower concentrations in the environment, are less likely to persist after release, and degrade (Lindahl 1993; Deagle et al. 2006; Hanfling et al. 2016; Bista et al. 2017). (Jo et al. 2017) showed that the decay rate of eDNA varied depending on the length of the DNA fragment, while (Hanfling et al. 2016) found that smaller ( 100 bp) fragments of $12 \mathrm{~S}$ rRNA persisted longer in lake water than longer ( $460 \mathrm{bp})$ fragments of cytochrome b (CytB). (Olson et al. 2012b) reported that primers targeting the mtDNA of the eastern hellbender (Cryptobranchus alleganiensis) had six orders of magnitude higher sensitivity than primers targeting the nuclear DNA. It has also been observed that polymerase choice can affect both occurrence and relative abundance estimates and the main source of this bias can be attributed to polymerase preference for sequences with specific GC contents (Fonseca 2018; Nichols et al. 2018). The addition of short indices to PCR primers can also introduce biases to the resulting sequence counts, especially in mixed-template eDNA samples, presumably via differential 
amplification efficiency among templates (O’Donnell et al. 2016; Leray \& Knowlton 2017). PCR amplification strategies also influence species detection and abundance estimation, with quantitative PCR (qPCR) being relatively more effective for species detection and abundance estimation than conventional PCR (cPCR) (Takahara et al. 2012; Turner et al. 2014b; Piggott 2016; Harper et al. 2018).

\section{iv. Variation in DNA copy number of target loci}

Environmental DNA studies have mostly relied on mitochondrial (mt), chloroplast (cp), and nuclear (n) DNA sequences, but the gene copy number of these target loci may vary between taxa, individuals or tissues, even when the same number of cells is present in an environmental sample (Moraes 2001; Morley \& Nielsen 2016; Minamoto et al. 2017; Nichols et al. 2018). This distorts the assumption that read abundance correlates with genic or taxon abundance, or that there is a constant copy number to individual relationship. For instance, (Minamoto et al. 2017) found that the copy numbers for nDNA of common carp (Cyprinus carpio) in environmental samples were considerably higher for mtDNA, with the nDNA marker requiring much less survey effort than the mtDNA marker, while (Piggott 2016) found that the 18S nDNA marker required relatively higher survey effort to achieve a 0.95 detection probability for Macquarie perch (Macquaria australasica) than two 12S mtDNA markers. These differences between molecular markers can greatly influence species detection and abundance estimation, yet many eDNA studies do not address this issue.

\section{v. Sequence filtering stringency}

Sequence filtering is a routine process in eDNA analysis and occurs at multiple steps of the bioinformatics pipeline. For metabarcoding, raw sequence data are initially processed to filter 
and correct (where possible) low-quality and erroneous reads (Valentini et al. 2016a; Evans et al. 2017a; Günther et al. 2018; Bakker et al. 2019; Rytkonen et al. 2019; Cowart et al. 2020; Zhang et al. 2020a). This quality control step removes any phiX reads (common in marker gene sequencing) and chimeric sequences detected in the raw sequencing data. Other quality filtering criteria include trimming off the first $m$ bases of each sequence, and/or truncating each sequence at position $n$ (Bakker et al. 2019; Cowart et al. 2020). The appropriate number of bases to be trimmed and the truncation length can be determined using read quality profiles. Filtering can also be performed on an OTU-table or a species-by-site matrix to remove samples with a total read frequency less than a given threshold and/or OTUs observed in less than a given number of samples (Bakker et al. 2019; Rytkonen et al. 2019; Cowart et al. 2020; Zhang et al. 2020a).

Filtering out OTUs that are detected in only one or a few samples is common, and this is based on the suspicion that these low frequency OTUs are PCR or sequencing errors (Bakker et al. 2019; Rytkonen et al. 2019; Cowart et al. 2020; Zhang et al. 2020a). Taxonomy-based filtering is also being applied to retain target taxa and/or exclude non-target taxa from eDNA analysis (Bakker et al. 2019; Cowart et al. 2020; Zhang et al. 2020a). Although there are accepted thresholds, across studies, about which filtering criteria are suitable, differences in sequencing depth, marker region, primer specificity, and taxonomic breadth makes it difficult to reach a general consensus (Evans et al. 2017a). Sequence filtering stringency can affect species detection, abundance and biomass quantification (Rivera et al. 2020). More stringent thresholds might filter out true biological sequences from the dataset, whereas more flexible thresholds might treat artefacts as true biological sequences (Laroche et al. 2017; Alberdi et al. 2018). (AMEND et al. 2010) reported a tradeoff between sequence quality stringency and quantification by showing 
that read-quality based processing stringency profoundly affected the abundance estimate for one fungal species.

\subsection{Incomplete reference databases and taxonomic assignment biases}

Environmental DNA of complex eukaryotic communities is increasingly being used to quantify biodiversity in terrestrial, freshwater and marine ecosystems (Civade et al. 2016;

Andruszkiewicz et al. 2017; Gillet et al. 2018; Fujii et al. 2019; Thomsen \& Sigsgaard 2019). Assignment of OTUs to species or higher taxonomic levels is a fundamental step in such studies. However, the incompleteness of reference sequence databases for most organisms is an important limitation for biodiversity studies using eDNA (Thomsen \& Sigsgaard 2019). The taxonomic identification of taxa is as good as the reference database used (Thomsen \& Sigsgaard 2019). Reference sequences for taxonomic assignment are only available for one or a few genes for most species and the targeted marker regions (e.g. COI, 12S, 16S) cannot accurately resolve most groups to species or higher taxonomic levels due to incompleteness of reference sequence databases (Deagle et al. 2014; Liu et al. 2017; Thomsen \& Sigsgaard 2019). Consequently, eDNA studies are often interpreted using molecular operational taxonomic units (MOTUs) or higher taxonomic ranks (genus, family, order) instead of binomial species names (Thomsen \& Sigsgaard 2019). This makes it difficult to associate eDNA data with existing biological and ecological knowledge. Although user-friendly and cost-efficient methods that generate fulllength reference barcodes could improve future eDNA studies (Liu et al. 2017), unbalanced barcoding efforts across regions of the world, taxonomic groups, and molecular markers (Ratnasingham \& Hebert 2007; Machida et al. 2017; Porter \& Hajibabaei 2018) currently limit the application of eDNA in ecology and conservation.

\subsection{Limited understanding of the ecology of eDNA}


We lack a clear understanding of the ecology of eDNA - its origin, state, transport, and fate. This information is critical for deciding whether eDNA sampling is the appropriate technique to make robust inferences about an organism's presence, and to quantify abundance (Turner et al. 2014a; Barnes \& Turner 2016; Stewart 2019). Environmental DNA originates as urine, feces, epidermal tissues, secretions, reproductive cells or carcasses and this source material enters the environment as particles of various sizes. These sources of eDNA may be rapidly transported from the site of release, including leaching into the soil, downstream flow and dispersion by water currents. Although particle size may be a major determinant of movement velocity, intact genomic DNA within living cells may be transformed into extracellular fractions too small to be detected (Barnes et al. 2014). (Murakami et al. 2019) found that eDNA of striped jack was mostly detectable within $30 \mathrm{~m}$ of the source, (Jane et al. 2015) found that eDNA of brook trout (Salvelinus fontinalis) could be detected 240 m downstream, (Deiner \& Altermatt 2014a) found that eDNA of daphnia (Daphnia longispina) could be detected $12.3 \mathrm{~km}$ downstream, and eDNA of pelecypod (Unio tumidus) could be detected $9.1 \mathrm{~km}$ downstream. Despite the fact that eDNA reflects the source within a range of distances (10-150 m; (O'Donnell et al. 2017; Yamamoto et al. 2017; Murakami et al. 2019), the relationship between water current and eDNA transport is not well known. Besides distance, many interacting factors can also influence eDNA detection after leaving its source (Pilliod et al. 2014).

It is unlikely that all organisms release equal amounts of DNA into the environment and that DNA from different sources degrades at the same rate, even under similar environmental conditions. Therefore, the detection of a target species may be influenced by eDNA release and degradation, which are in turn related to a species' size, life history, biotic interactions, and abiotic conditions (Barnes et al. 2014). For freshwater fish, eDNA degradation rates vary from 
10.5\%/h in common carp (Cyprinus carpio; (Barnes et al. 2014)) to $15.9 \% / \mathrm{h}$ in bluegill sunfish (Lepomis macrochirus; (Maruyama et al. 2014)), while for marine fish, eDNA degradation rates vary from 1.5\%/h in three-spined stickleback (Gasterosteus aculeatus; (Thomsen et al. 2012b)), 4.6\%/h in European flounder (Platichthys flesus; (Thomsen et al. 2012b)) to $>5.0 \% / \mathrm{h}$ in northern anchovy (Engraulis mordax), Pacific sardine (Sardinops sagax), and Pacific chub mackerel (Scomber japonicas) (Sassoubre et al. 2016). These studies suggest that the degradation rate of eDNA in aquatic fish, for instance, exhibit both species and environment effects.

DNA released into any environment is subjected to dynamic biological, physical, and chemical processes that determine its fate (Levy-Booth et al. 2007). After release, DNA may be bound to organic and inorganic particles that settle, and are later resuspended through natural phenomena like erosion, turbulence caused by fast-flow hydrological events, wind and wave action or bioturbation. However, whether eDNA is most abundant in the upper layer close to the source (surface, (Moyer et al. 2014; Murakami et al. 2019)) or in the lower layer away from the source (bottom, (Turner et al. 2015)) needs further investigation.

\subsection{Inconsistencies in data analysis and interpretation}

An important challenge in eDNA analysis is dealing with errors that occur during PCR amplification and sequencing in a consistent way. Researchers have attempted to ameliorate this issue using a variety of techniques including the deliberate and careful removal of erroneous sequences.

\section{i. Minimum sequence threshold}

Setting a minimum sequence copy number below which sequences are discarded is the most widely used strategy for eliminating erroneous sequences (Alberdi et al. 2018). However, this 
minimum sequence threshold varies considerably across eDNA studies, with some researchers only discarding singletons (i.e. a read with a sequence that is present only once (Andruszkiewicz et al. 2017; Bista et al. 2017; Yamamoto et al. 2017)), while others only consider sequences represented by $\geq 10$ identical reads for downstream analyses (e.g. (Fujii et al. 2019)). In any case, erroneous sequences must be removed with caution: more stringent thresholds might filter out rare biological sequences from the dataset, whereas more flexible thresholds might treat artefacts as true diversity (Laroche et al. 2017; Alberdi et al. 2018).

\section{ii. Chimeric sequence detection}

Chimeras are sequences formed when two or more biological sequences bind together during PCR (Judo et al. 1998; Edgar et al. 2011). Chimera formation is common in eDNA analysis, especially when DNA from closely related organisms is amplified (Edgar et al. 2011; Aas et al. 2017). Since chimeric sequences are very similar to their parent sequences (i.e. low divergence) and sometimes have identical sequences to valid genes, it is very challenging to distinguish chimeras from true biological sequences, even with dedicated software and complete reference sequence databases (Edgar 2016; Aas et al. 2017; Alberdi et al. 2018). Detection and removal of chimeras is of critical importance in eDNA studies because undetected chimeras can be misinterpreted as real biological entities or novel taxa, causing inflated estimates of true diversity and spurious inferences of differences in community composition (Edgar et al. 2011; Aas et al. 2017).

\section{iii. Clustering strategy and percent identity cutoff for OTU assignment}

eDNA metabarcoding typically clusters amplicon sequences into operational taxonomic units (OTUs) as an initial step in data processing. Many quality assurance and quality control 
648

649

650

651

652

653

654

655

656

657

658

659

660

661

662

663

664

665

666

667

668

669

approaches, such as denoising, also require sequence clustering prior to further analyses, including abundance and diversity estimation. Clustering groups sequences into OTUs based on percent identity thresholds that represent intraspecific differences and approximate species boundaries (Alberdi et al. 2018). The choice of clustering strategy for OTUs is crucial for estimating the true diversity of biological communities, so choosing the wrong strategy may result in either inflated or underestimated species richness and affect final conclusions (Alberdi et al. 2018; Xiong \& Zhan 2018; Rytkonen et al. 2019). While OTUs are typically constructed using a percent identity cutoff of $97 \%$ (Bista et al. 2017; Bista et al. 2018), lower and higher thresholds (Fujii et al. 2019; Rytkonen et al. 2019) have also been used. Moreover, lineages evolve at variable rates, so no single cut-off value can accommodate the entire tree of life.

Developers of other programs, such as Swarm, argue that a single global clustering threshold will inevitably be too relaxed for slow-evolving lineages and too stringent for rapidly evolving ones (Mahe et al. 2014, 2015; Andruszkiewicz et al. 2017; Sawaya et al. 2019).

\section{iv. Taxonomic assignment threshold}

Taxonomic assignment is performed using a wide variety of methods and programs, but in general, a search of reference sequence databases is conducted and query sequences (OTUs) within a predefined percent similarity to the reference sequence are assigned to the lowest possible taxonomic level. Taxonomic assignments may be considered valid if the percent similarity is above the predefined threshold, but some studies use different similarity thresholds to make assignments at different taxonomic levels, while some programs generate taxonomic predictions with confidence estimates specified by bootstrapping (Andruszkiewicz et al. 2017; Alberdi et al. 2018; Bista et al. 2018). Sometimes, OTUs are discarded because they do not 
670

671

672

673

674

675

676

677

678

679

680

681

682

683

684

685

686

687

688

689

690

691

match any sequence in the reference database (Laroche et al. 2017). This is problematic for accurate abundance and diversity estimation.

\subsection{Lack of ecological information}

eDNA analyses mostly report presence/absence and/or recent occupancy. Information on the ecological status of target organisms, including the life history stages (adults, eggs, larvae) present, the sex ratio, body condition (sick or healthy), and activity (e.g. breeding or nonbreeding) cannot be obtained, but may be crucial for making informed management and conservation decisions. For instance, amphibians have complex life cycles and live both on land and in water, as eggs, tadpoles or adults. Many amphibians are highly threatened and each threat operates on different, sometimes multiple, life history stages (Klein et al. 2017). Thus, knowledge of an organism's life history stages and their respective threats is critical for effective management of their population (Klein et al. 2017). Moreover, life history traits that cannot be assessed using eDNA can be key considerations for designing a successful eDNA-based study. For instance, a species' life history can influence how well (when, where, and how) it can be detected via eDNA surveys (Olson et al. 2012a; Barnes \& Turner 2016; Bylemans et al. 2017; Eiler et al. 2018; Takeuchi et al. 2019a; Wineland et al. 2019).

\section{Potential ways of reducing limitations in eDNA analysis}

Researchers have long been focusing on the comparisons between the detection probability of eDNA and traditional survey methods (Ficetola et al. 2008; Jerde et al. 2011b). But only recently have they begun to explore the origin, state, transport, and fate of eDNA and how these attributes influence species detection and quantification, data analysis, and result interpretation (Deiner \& Altermatt 2014b; Barnes \& Turner 2016; Jerde et al. 2016; Collins et al. 2018; Lugg et al. 2018; 


\begin{tabular}{|c|c|c|c|}
\hline Challenge and limitation & Causes & Potential solution(s) & Reference (s) \\
\hline \multirow[t]{6}{*}{$\begin{array}{l}\text { Imperfect sampling of eDNA and } \\
\text { false detection }\end{array}$} & $\begin{array}{l}\text { Limited persistence of } \\
\text { eDNA }\end{array}$ & $\begin{array}{l}\text { Use multiple field and PCR replicates } \\
\text { Estimate detection rates using } \\
\text { occupancy or other models }\end{array}$ & $\begin{array}{l}\text { (Roussel et al. 2015; } \\
\text { Valentini et al. } \\
\text { 2016b; Willoughby } \\
\text { et al. 2016; Alberdi } \\
\text { et al. 2018) }\end{array}$ \\
\hline & PCR primer biases & $\begin{array}{l}\text { Use multiple markers and primers, } \\
\text { even when targeting the same } \\
\text { taxonomic group }\end{array}$ & $\begin{array}{l}\text { (Alberdi et al. 2018; } \\
\text { Collins et al. 2019) }\end{array}$ \\
\hline & $\begin{array}{l}\text { Inhibition of DNA } \\
\text { amplification }\end{array}$ & Use inhibition-reducing assays & (Jane et al. 2015) \\
\hline & Sample contamination & $\begin{array}{l}\text { Use negative and positive controls } \\
\text { Use particle size-based selective } \\
\text { capture/enrichment of target eDNA }\end{array}$ & $\begin{array}{l}\text { (Turner et al. 2014a; } \\
\text { Bista et al. 2017) }\end{array}$ \\
\hline & $\begin{array}{l}\text { eDNA from dead } \\
\text { organisms }\end{array}$ & $\begin{array}{l}\text { Co-extract extracellular and } \\
\text { intracellular DNA } \\
\text { Co-extract DNA and RNA } \\
\text { Amplify both longer and shorter DNA } \\
\text { fragments }\end{array}$ & $\begin{array}{l}\text { (Bista } \text { et al. 2017; } \\
\text { Laroche } \text { et al. 2017) }\end{array}$ \\
\hline & $\begin{array}{l}\text { Ancient DNA (aDNA) } \\
\text { resuspension }\end{array}$ & $\begin{array}{l}\text { Confirm the organism's presence with } \\
\text { traditional surveys }\end{array}$ & (Wu et al. 2018) \\
\hline \multirow[t]{5}{*}{$\begin{array}{l}\text { Difficulties in quantifying abundance } \\
\text { and biomass }\end{array}$} & $\begin{array}{l}\text { Variability in eDNA } \\
\text { deposition and } \\
\text { preservation }\end{array}$ & $\begin{array}{l}\text { Quantify the relationship between } \\
\text { eDNA release and biotic, and abiotic } \\
\text { factors }\end{array}$ & $\begin{array}{l}\text { (Laramie et al. } \\
\text { 2015; Sassoubre et } \\
\text { al. 2016) }\end{array}$ \\
\hline & $\begin{array}{l}\text { Choice of eDNA } \\
\text { sampling and processing } \\
\text { protocols }\end{array}$ & $\begin{array}{l}\text { Use fully integrated environmental } \\
\text { DNA sampling systems }\end{array}$ & (Thomas et al. 2018) \\
\hline & $\begin{array}{l}\text { PCR primer and } \\
\text { sequencing biases }\end{array}$ & $\begin{array}{l}\text { Use PCR-free and capture-based } \\
\text { approaches }\end{array}$ & $\begin{array}{l}\text { (Zhou et al. 2013; } \\
\text { Wilcox et al. 2018; } \\
\text { Ji et al. 2019) }\end{array}$ \\
\hline & $\begin{array}{l}\text { Variation in DNA copy } \\
\text { number of target loci }\end{array}$ & Use multiple DNA markers & $\begin{array}{l}\text { (Ma et al. 2016; } \\
\text { Bylemans et al. } \\
\text { 2018) }\end{array}$ \\
\hline & $\begin{array}{l}\text { Sequence filtering } \\
\text { stringency }\end{array}$ & $\begin{array}{l}\text { Adapt workflows based on sequencing } \\
\text { technology and library }\end{array}$ & (Divoll et al. 2018) \\
\hline
\end{tabular}




\begin{tabular}{|l|l|l|l|}
\hline Taxonomic assignment biases & $\begin{array}{l}\text { Incomplete reference } \\
\text { databases }\end{array}$ & Increase barcode efforts & (Young et al. $)$ \\
\hline $\begin{array}{l}\text { Limited understanding of the ecology } \\
\text { of eDNA }\end{array}$ & $\begin{array}{l}\text { eDNA origin, state, } \\
\text { transport, and fate }\end{array}$ & $\begin{array}{l}\text { Use experimental validation in } \\
\text { laboratory and natural settings }\end{array}$ & $\begin{array}{l}\text { (Barnes \& Turner } \\
\text { 2016; Maruyama } \text { et } \\
\text { al. } 2019 ; \text { Murakami } \\
\text { et al. 2019) }\end{array}$ \\
\hline $\begin{array}{l}\text { Inconsistencies in data analysis and } \\
\text { interpretation }\end{array}$ & $\begin{array}{l}\text { Minimum sequence } \\
\text { threshold }\end{array}$ & $\begin{array}{l}\text { Use relative thresholds (e.g. 0.01\% of } \\
\text { total reads) rather than absolute copy } \\
\text { number thresholds }\end{array}$ & $\begin{array}{l}\text { (Bista } \text { et al. 2017; } \\
\text { Alberdi } \text { et al. 2018) }\end{array}$ \\
\hline & $\begin{array}{l}\text { Chimeric sequence } \\
\text { detection and removal }\end{array}$ & $\begin{array}{l}\text { Predict in silico and remove using de } \\
\text { novo delimitation approaches }\end{array}$ & $\begin{array}{l}\text { (Bista } \text { et al. 2017; } \\
\text { Alberdi } \text { et al. 2018) }\end{array}$ \\
\hline Lack of ecological information & $\begin{array}{l}\text { Percent identity for OTU } \\
\text { clustering }\end{array}$ & $\begin{array}{l}\text { Use existing knowledge of } \\
\text { intraspecific diversity for target taxa }\end{array}$ & (Bista et al. 2017) \\
\hline taxonomic assignment & $\begin{array}{l}\text { Evaluate the completeness and } \\
\text { accuracy of reference database used }\end{array}$ & (Bista et al. 2017) \\
\hline
\end{tabular}

697 
700

701

702

703

eDNA and traditional survey methods should not usually be considered as alternative methods for assessing and monitoring biodiversity, since they can give such different information (Ulibarri et al. 2017; Bailey et al. 2019; Rose et al. 2019; Leempoel et al. 2020; Takahara et al. 2020). Researchers must consider which of the two methods — or the use of both — is most appropriate for addressing the questions they want to investigate (Qu \& Stewart 2019b). Information from eDNA often needs to be followed up with traditional surveys, but eDNA can help guide these surveys in the right direction (Rose et al. 2019; Ji et al. 2020; Sales et al. 2020). For example, Ji et al. 2020 found that leech-derived eDNA provides valuable information on the spatial distributions of vertebrate species and on the environmental and anthropogenic correlates of those distributions, making it a useful tool to efficiently measure the effectiveness of protected areas and to help optimize the deployment of management resources within reserves. The way in which eDNA and traditional surveys are implemented will largely be determined by the research questions, but will also be influenced by practical considerations, such as the availability of resources (including funding, time and the knowledge and skills of the persons undertaking the research), and sound methodology. Knowing when to employ eDNA techniques rather than—or in addition to - traditional sampling would enable practitioners to make more informed choices concerning data collection (Franklin et al. 2019; Qu \& Stewart 2019b). Based on the proportion of eDNA studies published (between 1 January 2008 and 31 December 2019, Figure 2), eDNA might be the first choice for hard-to-collect aquatic species (e.g. marine macroinvertebrates) and would probably always be a useful supplement for fish and other cryptic aquatic species (Wineland et al. 2019). The complex nature of some projects can sometimes make it difficult for all aspects of a research question to be answered by a single method. In such cases, more than 
722 one method can be used to collect and analyze data, integrate the findings, and draw inferences

723 (Harper et al. 2019; Jeunen et al. 2019; Knudsen et al. 2019; Wineland et al. 2019). eDNA can

724 be an exceptionally useful ecological and conservation tool when used in combination with

725 historical and other sources of data (e.g. citizen science) (Tingley et al. 2019). However, if

726 conditions permit, traditional biodiversity surveys will usually still be the first choice, because of

727 the additional types of information they can provide. 


\section{Number of eDNA studies}

\section{Terrestrial}

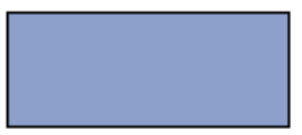

Marine

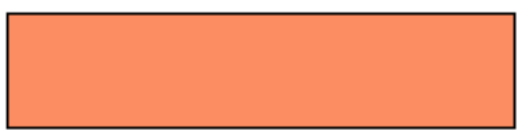

Freshwater

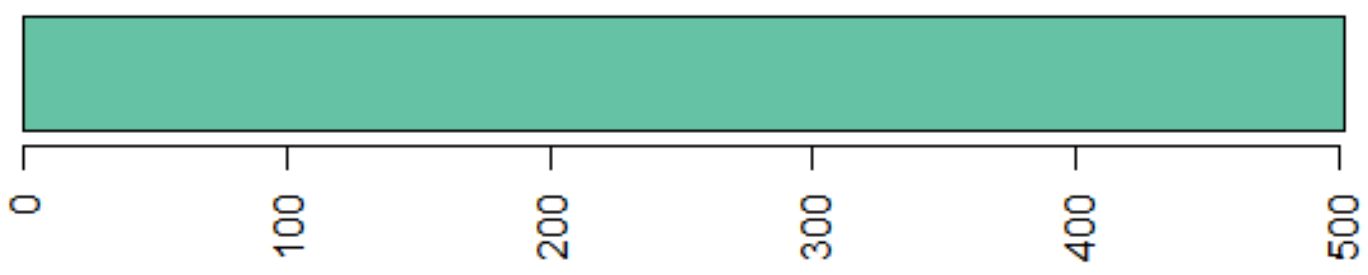

Reptile

Plants

Others

Mammal

Invertebrates

Fish

Bird

Amphibian
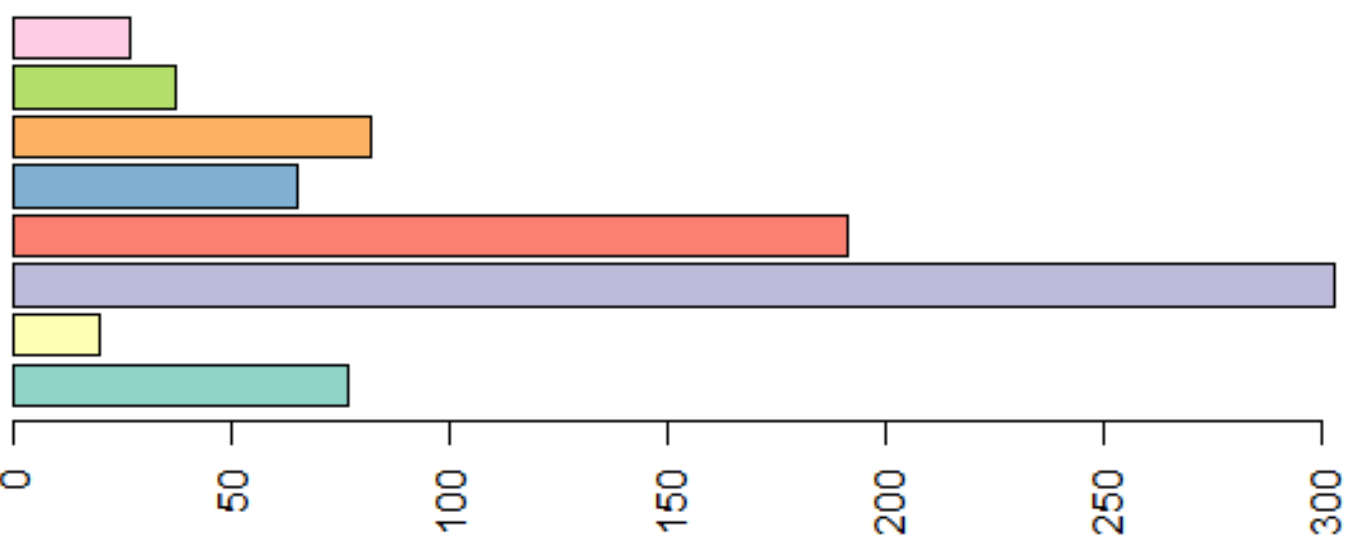

Figure 2 Number of studies using environmental DNA (eDNA) recovered from a literature search with the

that utilized a different organismal group and ecosystem.

\section{References}

Aas, A.B., Davey, M.L. \& Kauserud, H. (2017). ITS all right mama: investigating the formation of chimeric sequences in the ITS2 region by DNA metabarcoding analyses of fungal mock communities of different complexities. Mol Ecol Resour, 17, 730-741.

Akamatsu, Y., Kume, G., Gotou, M., Kono, T., Fujii, T., Inui, R. et al. (2020). Using environmental DNA analyses to assess the occurrence and abundance of the endangered amphidromous fish Plecoglossus altivelis ryukyuensis. Biodiversity Data Journal, 8.

Akre, T.S., Parker, L.D., Ruther, E., Maldonado, J.E., Lemmon, L. \& Mclnerney, N.R. (2019). Concurrent visual encounter sampling validates eDNA selectivity and sensitivity for the endangered wood turtle (Glyptemys insculpta). Plos One, 14. 
Alberdi, A., Aizpurua, O., Gilbert, M.T.P. \& Bohmann, K. (2018). Scrutinizing key steps for reliable metabarcoding of environmental samples. Methods Ecol Evol, 9, 134-147.

Alexander, J.B., Bunce, M., White, N., Wilkinson, S.P., Adam, A.A.S., Berry, T. et al. (2020). Development of a multi-assay approach for monitoring coral diversity using eDNA metabarcoding. Coral Reefs, 39, 159-171.

Amberg, J.J., Merkes, C.M., Stott, W., Rees, C.B. \& Erickson, R.A. (2019). Environmental DNA as a tool to help inform zebra mussel, Dreissena polymorpha, management in inland lakes. Manag Biol Invasion, 10, 96-110.

AMEND, A.S., SEIFERT, K.A. \& BRUNS, T.D. (2010). Quantifying microbial communities with 454 pyrosequencing: does read abundance count? Mol Ecol, 19, 5555-5565.

ANDERSEN, K., BIRD, K.L., RASMUSSEN, M., HAILE, J., BREUNING-MADSEN, H., KJ/ER, K.H. et al. (2012a). Meta-barcoding of 'dirt' DNA from soil reflects vertebrate biodiversity. Mol Ecol, 21, 1966-1979.

Andersen, K., Bird, K.L., Rasmussen, M., Haile, J., Breuning-Madsen, H., Kjaer, K.H. et al. (2012b). Metabarcoding of 'dirt' DNA from soil reflects vertebrate biodiversity. Mol Ecol, 21, 1966-1979.

Andruszkiewicz, E.A., Starks, H.A., Chavez, F.P., Sassoubre, L.M., Block, B.A. \& Boehm, A.B. (2017). Biomonitoring of marine vertebrates in Monterey Bay using eDNA metabarcoding. PloS one, 12, e0176343-e0176343.

Anglès d'Auriac, M.B., Strand, D.A., Mjelde, M., Demars, B.O.L. \& Thaulow, J. (2019). Detection of an invasive aquatic plant in natural water bodies using environmental DNA. Plos One, 14, e0219700.

Antognazza, C.M., Britton, J.R., Potter, C., Franklin, E., Hardouin, E.A., Gutmann Roberts, C. et al. (2019a). Environmental DNA as a non-invasive sampling tool to detect the spawning distribution of European anadromous shads (Alosa spp.). Aquatic Conservation: Marine and Freshwater Ecosystems, 29, 148-152.

Antognazza, C.M., Britton, J.R., Potter, C., Franklin, E., Hardouin, E.A., Roberts, C.G. et al. (2019b). Environmental DNA as a non-invasive sampling tool to detect the spawning distribution of European anadromous shads (Alosa spp.). Aquat Conserv, 29, 148-152.

Ardura, A. (2019). Species-specific markers for early detection of marine invertebrate invaders through eDNA methods: Gaps and priorities in GenBank as database example. J Nat Conserv, 47, 51-57.

Bailey, L.L., Jones, P., Thompson, K.G., Foutz, H.P., Logan, J.M., Wright, F.B. et al. (2019). Determining Presence of Rare Amphibian Species: Testing and Combining Novel Survey Methods. J Herpetol, 53, 115-124.

Bakker, J., Wangensteen, O.S., Baillie, C., Buddo, D., Chapman, D.D., Gallagher, A.J. et al. (2019). Biodiversity assessment of tropical shelf eukaryotic communities via pelagic eDNA metabarcoding. Ecol Evol, 9, 14341-14355.

Balasingham, K.D., Walter, R.P. \& Heath, D.D. (2017). Residual eDNA detection sensitivity assessed by quantitative real-time PCR in a river ecosystem. Mol Ecol Resour, 17, 523-532.

Baldigo, B.P., Sporn, L.A., George, S.D. \& Ball, J.A. (2017). Efficacy of Environmental DNA to Detect and Quantify Brook Trout Populations in Headwater Streams of the Adirondack Mountains, New York. T Am Fish Soc, 146, 99-111.

Barnes, M.A. \& Turner, C.R. (2016). The ecology of environmental DNA and implications for conservation genetics. Conservation Genetics, 17, 1-17.

Barnes, M.A., Turner, C.R., Jerde, C.L., Renshaw, M.A., Chadderton, W.L. \& Lodge, D.M. (2014). Environmental Conditions Influence eDNA Persistence in Aquatic Systems. Environ Sci Technol, 48, 1819-1827.

Basset, Y., Cizek, L., Cuénoud, P., Didham, R.K., Guilhaumon, F., Missa, O. et al. (2012). Arthropod Diversity in a Tropical Forest. Science, 338, 1481-1484. 
Beauclerc, K., Wozney, K., Smith, C. \& Wilson, C. (2019). Development of quantitative PCR primers and probes for environmental DNA detection of amphibians in Ontario. Conserv Genet Resour, 11, 43-46.

Bedwell, M.E. \& Goldberg, C.S. (2020). Spatial and temporal patterns of environmental DNA detection to inform sampling protocols in lentic and lotic systems. Ecol Evol.

Bienert, F., De Danieli, S., Miquel, C., Coissac, E., Poillot, C., Brun, J.J. et al. (2012). Tracking earthworm communities from soil DNA. Mol Ecol, 21, 2017-2030.

Biggs, J., Ewald, N., Valentini, A., Gaboriaud, C., Dejean, T., Griffiths, R.A. et al. (2015). Using eDNA to develop a national citizen science-based monitoring programme for the great crested newt (Triturus cristatus). Biol Conserv, 183, 19-28.

Bista, I., Carvalho, G.R., Tang, M., Walsh, K., Zhou, X., Hajibabaei, M. et al. (2018). Performance of amplicon and shotgun sequencing for accurate biomass estimation in invertebrate community samples. Mol Ecol Resour, 18, 1020-1034.

Bista, I., Carvalho, G.R., Walsh, K., Seymour, M., Hajibabaei, M., Lallias, D. et al. (2017). Annual timeseries analysis of aqueous eDNA reveals ecologically relevant dynamics of lake ecosystem biodiversity. Nat Commun, 8, 14087.

Bracken, F.S.A., Rooney, S.M., Kelly-Quinn, M., King, J.J. \& Carlsson, J. (2019). Identifying spawning sites and other critical habitat in lotic systems using eDNA "snapshots": A case study using the sea lamprey Petromyzon marinus L. Ecol Evol, 9, 553-567.

Brannock, P.M. \& Halanych, K.M. (2015). Meiofaunal community analysis by high-throughput sequencing: Comparison of extraction, quality filtering, and clustering methods. Mar Genom, 23, 67-75.

Burivalova, Z., Game, E.T. \& Butler, R.A. (2019). The sound of a tropical forest. Science, 363, 28-29.

Buxton, A.S., Groombridge, J.J., Zakaria, N.B. \& Griffiths, R.A. (2017). Seasonal variation in environmental DNA in relation to population size and environmental factors. Scientific Reports, 7.

Bylemans, J., Furlan, E.M., Gleeson, D.M., Hardy, C.M. \& Duncan, R.P. (2018). Does Size Matter? An Experimental Evaluation of the Relative Abundance and Decay Rates of Aquatic Environmental DNA. Environ Sci Technol, 52, 6408-6416.

Bylemans, J., Furlan, E.M., Hardy, C.M., McGuffie, P., Lintermans, M. \& Gleeson, D.M. (2017). An environmental DNA-based method for monitoring spawning activity: a case study, using the endangered Macquarie perch (Macquaria australasica). Methods Ecol Evol, 8, 646-655.

Cannon, M.V., Hester, J., Shalkhauser, A., Chan, E.R., Logue, K., Small, S.T. et al. (2016). In silico assessment of primers for eDNA studies using PrimerTree and application to characterize the biodiversity surrounding the Cuyahoga River. Scientific Reports, 6, 22908.

Carraro, L., Hartikainen, H., Jokela, J., Bertuzzo, E. \& Rinaldo, A. (2018). Estimating species distribution and abundance in river networks using environmental DNA. Proceedings of the National Academy of Sciences, 115, 11724-11729.

Carvalho, S., Aylagas, E., Villalobos, R., Kattan, Y., Berumen, M. \& Pearman, J.K. (2019). Beyond the visual: using metabarcoding to characterize the hidden reef cryptobiome. P Roy Soc B-Biol Sci, 286.

Champlot, S., Berthelot, C., Pruvost, M., Bennett, E.A., Grange, T. \& Geigl, E.M. (2010). An Efficient Multistrategy DNA Decontamination Procedure of PCR Reagents for Hypersensitive PCR Applications. Plos One, 5.

Chen, W.T. \& Ficetola, G.F. (2019). Conditionally autoregressive models improve occupancy analyses of autocorrelated data: An example with environmental DNA. Mol Ecol Resour, 19, 163-175.

Cilleros, K., Valentini, A., Allard, L., Dejean, T., Etienne, R., Grenouillet, G. et al. (2019). Unlocking biodiversity and conservation studies in high-diversity environments using environmental DNA (eDNA): A test with Guianese freshwater fishes. Mol Ecol Resour, 19, 27-46. 
Civade, R., Dejean, T., Valentini, A., Roset, N., Raymond, J.-C., Bonin, A. et al. (2016). Spatial Representativeness of Environmental DNA Metabarcoding Signal for Fish Biodiversity Assessment in a Natural Freshwater System. PloS one, 11, e0157366-e0157366.

Clare, E.L., Symondson, W.O.C., Broders, H., Fabianek, F., Fraser, E.E., MacKenzie, A. et al. (2014). The diet of Myotis lucifugus across Canada: assessing foraging quality and diet variability. Mol Ecol, 23, 3618-3632.

Clarke, A. \& Fraser, K.P.P. (2004). Why does metabolism scale with temperature? Functional Ecology, 18, 243-251.

Collins, R.A., Bakker, J., Wangensteen, O.S., Soto, A.Z., Corrigan, L., Sims, D.W. et al. (2019). Non-specific amplification compromises environmental DNA metabarcoding with COI. Methods Ecol Evol.

Collins, R.A., Wangensteen, O.S., O’Gorman, E.J., Mariani, S., Sims, D.W. \& Genner, M.J. (2018). Persistence of environmental DNA in marine systems. Communications Biology, 1, 185.

Cordier, T., Frontalini, F., Cermakova, K., Apothéloz-Perret-Gentil, L., Treglia, M., Scantamburlo, E. et al. (2019). Multi-marker eDNA metabarcoding survey to assess the environmental impact of three offshore gas platforms in the North Adriatic Sea (Italy). Marine Environmental Research, 146, 2434.

Corlett, R.T. (2017). A Bigger Toolbox: Biotechnology in Biodiversity Conservation. Trends Biotechnol, 35, 55-65.

Cowart, D.A., Matabos, M., Brandt, M.I., Marticorena, J. \& Sarrazin, J. (2020). Exploring Environmental DNA (eDNA) to Assess Biodiversity of Hard Substratum Faunal Communities on the Lucky Strike Vent Field (Mid-Atlantic Ridge) and Investigate Recolonization Dynamics After an Induced Disturbance. Front Mar Sci, 6.

Davy, C.M., Kidd, A.G. \& Wilson, C.C. (2015). Development and Validation of Environmental DNA (eDNA) Markers for Detection of Freshwater Turtles. Plos One, 10, e0130965-e0130965.

de Souza, L.S., Godwin, J.C., Renshaw, M.A. \& Larson, E. (2016). Environmental DNA (eDNA) Detection Probability Is Influenced by Seasonal Activity of Organisms. Plos One, 11.

Deagle, B.E., Eveson, J.P. \& Jarman, S.N. (2006). Quantification of damage in DNA recovered from highly degraded samples--a case study on DNA in faeces. Front Zool, 3, 11.

Deagle, B.E., Jarman, S.N., Coissac, E., Pompanon, F. \& Taberlet, P. (2014). DNA metabarcoding and the cytochrome c oxidase subunit I marker: not a perfect match. Biology letters, 10, 20140562.

Deagle, B.E., Kirkwood, R. \& Jarman, S.N. (2009). Analysis of Australian fur seal diet by pyrosequencing prey DNA in faeces. Mol Ecol, 18, 2022-2038.

Deagle, B.E., Thomas, A.C., Shaffer, A.K., Trites, A.W. \& Jarman, S.N. (2013). Quantifying sequence proportions in a DNA-based diet study using lon Torrent amplicon sequencing: which counts count? Mol Ecol Resour, 13, 620-633.

Deiner, K. \& Altermatt, F. (2014a). Transport distance of invertebrate environmental DNA in a natural river. PloS one, 9, e88786-e88786.

Deiner, K. \& Altermatt, F. (2014b). Transport Distance of Invertebrate Environmental DNA in a Natural River. PLOS ONE, 9, e88786.

Deiner, K., Bik, H.M., Machler, E., Seymour, M., Lacoursiere-Roussel, A., Altermatt, F. et al. (2017). Environmental DNA metabarcoding: Transforming how we survey animal and plant communities. Mol Ecol, 26, 5872-5895.

Deiner, K., Fronhofer, E.A., Mächler, E., Walser, J.-C. \& Altermatt, F. (2016). Environmental DNA reveals that rivers are conveyer belts of biodiversity information. Nat Commun, 7, 12544.

Deiner, K., Walser, J.-C., Mächler, E. \& Altermatt, F. (2015a). Choice of capture and extraction methods affect detection of freshwater biodiversity from environmental DNA. Biological Conservation, 183, 53-63. 
Deiner, K., Walser, J.C., Machler, E. \& Altermatt, F. (2015b). Choice of capture and extraction methods affect detection of freshwater biodiversity from environmental DNA. Biol Conserv, 183, 53-63.

Dejean, T., Valentini, A., Duparc, A., Pellier-Cuit, S., Pompanon, F., Taberlet, P. et al. (2011). Persistence of Environmental DNA in Freshwater Ecosystems. Plos One, 6.

Dejean, T., Valentini, A., Miquel, C., Taberlet, P., Bellemain, E. \& Miaud, C. (2012). Improved detection of an alien invasive species through environmental DNA barcoding: the example of the American bullfrog Lithobates catesbeianus. J Appl Ecol, 49, 953-959.

Deutschmann, B., Mueller, A.-K., Hollert, H. \& Brinkmann, M. (2019). Assessing the fate of brown trout (Salmo trutta) environmental DNA in a natural stream using a sensitive and specific dual-labelled probe. Sci Total Environ, 655, 321-327.

DiBattista, J.D., Reimer, J.D., Stat, M., Masucci, G.D., Biondi, P., De Brauwer, M. et al. (2019). Digging for DNA at depth: rapid universal metabarcoding surveys (RUMS) as a tool to detect coral reef biodiversity across a depth gradient. Peerj, 7.

Divoll, T.J., Brown, V.A., Kinne, J., McCracken, G.F. \& O'Keefe, J.M. (2018). Disparities in secondgeneration DNA metabarcoding results exposed with accessible and repeatable workflows. Mol Ecol Resour, 18, 590-601.

Djurhuus, A., Closek, C.J., Kelly, R.P., Pitz, K.J., Michisaki, R.P., Starks, H.A. et al. (2020). Environmental DNA reveals seasonal shifts and potential interactions in a marine community. Nature Communications, 11, 254.

Djurhuus, A., Port, J., Closek, C.J., Yamahara, K.M., Romero-Maraccini, O., Walz, K.R. et al. (2017). Evaluation of Filtration and DNA Extraction Methods for Environmental DNA Biodiversity Assessments across Multiple Trophic Levels. Frontiers in Marine Science, 4.

Doi, H., Akamatsu, Y., Watanabe, Y., Goto, M., Inui, R., Katano, I. et al. (2017). Water sampling for environmental DNA surveys by using an unmanned aerial vehicle. Limnol Oceanogr-Meth, 15, 939-944.

Doi, H., Fukaya, K., Oka, S., Sato, K., Kondoh, M. \& Miya, M. (2019). Evaluation of detection probabilities at the water-filtering and initial PCR steps in environmental DNA metabarcoding using a multispecies site occupancy model. Scientific Reports, 9.

Doi, H., Uchii, K., Takahara, T., Matsuhashi, S., Yamanaka, H. \& Minamoto, T. (2015). Use of Droplet Digital PCR for Estimation of Fish Abundance and Biomass in Environmental DNA Surveys. Plos One, 10.

Dunn, N., Priestley, V., Herraiz, A., Arnold, R. \& Savolainen, V. (2017). Behavior and season affect crayfish detection and density inference using environmental DNA. Ecol Evol, 7, 7777-7785.

Edgar, R.C. (2016). UCHIME2: improved chimera prediction for amplicon sequencing. bioRxiv, 074252.

Edgar, R.C., Haas, B.J., Clemente, J.C., Quince, C. \& Knight, R. (2011). UCHIME improves sensitivity and speed of chimera detection. Bioinformatics, 27, 2194-2200.

Edwards, M.E., Alsos, I.G., Yoccoz, N., Coissac, E., Goslar, T., Gielly, L. et al. (2018). Metabarcoding of modern soil DNA gives a highly local vegetation signal in Svalbard tundra. Holocene, 28, 20062016.

Eichmiller, J.J., Miller, L.M. \& Sorensen, P.W. (2016). Optimizing techniques to capture and extract environmental DNA for detection and quantification of fish. Molecular Ecology Resources, 16, 56-68.

Eiler, A., Löfgren, A., Hjerne, O., Nordén, S. \& Saetre, P. (2018). Environmental DNA (eDNA) detects the pool frog (Pelophylax lessonae) at times when traditional monitoring methods are insensitive. Scientific Reports, 8, 5452. 
Elbrecht, V. \& Leese, F. (2015). Can DNA-Based Ecosystem Assessments Quantify Species Abundance? Testing Primer Bias and Biomass-Sequence Relationships with an Innovative Metabarcoding Protocol. PLOS ONE, 10, e0130324.

Epp, L.S., Boessenkool, S., Bellemain, E.P., Haile, J., Esposito, A., Riaz, T. et al. (2012). New environmental metabarcodes for analysing soil DNA: potential for studying past and present ecosystems. Mol Ecol, 21, 1821-1833.

Erickson, R.A., Rees, C.B., Coulter, A.A., Merkes, C.M., Mccalla, S.G., Touzinsky, K.F. et al. (2016). Detecting the movement and spawning activity of bigheaded carps with environmental DNA. Mol Ecol Resour, 16, 957-965.

Evans, N.T., Li, Y.Y., Renshaw, M.A., Olds, B.P., Deiner, K., Turner, C.R. et al. (2017a). Fish community assessment with eDNA metabarcoding: effects of sampling design and bioinformatic filtering. Can J Fish Aquat Sci, 74, 1362-1374.

Evans, N.T., Olds, B.P., Renshaw, M.A., Turner, C.R., Li, Y., Jerde, C.L. et al. (2016). Quantification of mesocosm fish and amphibian species diversity via environmental DNA metabarcoding. Mol Ecol Resour, 16, 29-41.

Evans, N.T., Shirey, P.D., Wieringa, J.G., Mahon, A.R. \& Lamberti, G.A. (2017b). Comparative Cost and Effort of Fish Distribution Detection via Environmental DNA Analysis and Electrofishing. Fisheries, 42, 90-99.

Evrard, O., Laceby, J.P., Ficetola, G.F., Gielly, L., Huon, S., Lefèvre, I. et al. (2019). Environmental DNA provides information on sediment sources: A study in catchments affected by Fukushima radioactive fallout. Science of The Total Environment, 665, 873-881.

Fernanda Nardi, C., Alfredo Fernandez, D., Alberto Vanella, F. \& Chalde, T. (2019). The expansion of exotic Chinook salmon (Oncorhynchus tshawytscha) in the extreme south of Patagonia: an environmental DNA approach. Biol Invasions, 21, 1415-1425.

Ficetola, G.F., Manenti, R. \& Taberlet, P. (2019). Environmental DNA and metabarcoding for the study of amphibians and reptiles: species distribution, the microbiome, and much more. AmphibiaReptilia, 40, 129-148.

Ficetola, G.F., Miaud, C., Pompanon, F. \& Taberlet, P. (2008). Species detection using environmental DNA from water samples. Biol Letters, 4, 423-425.

Ficetola, G.F., Pansu, J., Bonin, A., Coissac, E., Giguet-Covex, C., De Barba, M. et al. (2015). Replication levels, false presences and the estimation of the presence/absence from eDNA metabarcoding data. Mol Ecol Resour, 15, 543-556.

Ficetola, G.F., Taberlet, P. \& Coissac, E. (2016). How to limit false positives in environmental DNA and metabarcoding? Mol Ecol Resour, 16, 604-607.

Fonseca, V.G. (2018). "Pitfalls in relative abundance estimation using eDNA metabarcoding". Mol Ecol Resour, 18, 923-926.

Franklin, T.W., McKelvey, K.S., Golding, J.D., Mason, D.H., Dysthe, J.C., Pilgrim, K.L. et al. (2019). Using environmental DNA methods to improve winter surveys for rare carnivores: DNA from snow and improved noninvasive techniques. Biol Conserv, 229, 50-58.

Fraser, C.I., Connell, L., Lee, C.K. \& Cary, S.C. (2018). Evidence of plant and animal communities at exposed and subglacial (cave) geothermal sites in Antarctica. Polar Biol, 41, 417-421.

Fritts, A.K., Knights, B.C., Larson, J.H., Amberg, J.J., Merkes, C.M., Tajjioui, T. et al. (2019). Development of a quantitative PCR method for screening ichthyoplankton samples for bigheaded carps. Biol Invasions, 21, 1143-1153.

Fujii, K., Doi, H., Matsuoka, S., Nagano, M., Sato, H. \& Yamanaka, H. (2019). Environmental DNA metabarcoding for fish community analysis in backwater lakes: A comparison of capture methods. PloS one, 14, e0210357-e0210357. 
Fukumoto, S., Ushimaru, A. \& Minamoto, T. (2015). A basin-scale application of environmental DNA assessment for rare endemic species and closely related exotic species in rivers: a case study of giant salamanders in Japan. J Appl Ecol, 52, 358-365.

Galan, M., Pages, M. \& Cosson, J.F. (2012). Next-Generation Sequencing for Rodent Barcoding: Species Identification from Fresh, Degraded and Environmental Samples. Plos One, 7.

Galan, M., Pons, J.-B., Tournayre, O., Pierre, E., Leuchtmann, M., Pontier, D. et al. (2018). Metabarcoding for the parallel identification of several hundred predators and their prey: Application to bat species diet analysis. Mol Ecol Resour, 18, 474-489.

Gillet, B., Cottet, M., Destanque, T., Kue, K., Descloux, S., Chanudet, V. et al. (2018). Direct fishing and eDNA metabarcoding for biomonitoring during a 3-year survey significantly improves number of fish detected around a South East Asian reservoir. PloS one, 13, e0208592-e0208592.

Goldberg, C.S., Pilliod, D.S., Arkle, R.S. \& Waits, L.P. (2011). Molecular Detection of Vertebrates in Stream Water: A Demonstration Using Rocky Mountain Tailed Frogs and Idaho Giant Salamanders. Plos One, 6.

Goldberg, C.S., Sepulveda, A., Ray, A., Baumgardt, J. \& Waits, L.P. (2013). Environmental DNA as a new method for early detection of New Zealand mudsnails (Potamopyrgus antipodarum). Freshw Sci, $32,792-800$.

Goldberg, C.S., Strickler, K.M. \& Fremier, A.K. (2018). Degradation and dispersion limit environmental DNA detection of rare amphibians in wetlands: Increasing efficacy of sampling designs. Science of The Total Environment, 633, 695-703.

Goldberg, C.S., Turner, C.R., Deiner, K., Klymus, K.E., Thomsen, P.F., Murphy, M.A. et al. (2016). Critical considerations for the application of environmental DNA methods to detect aquatic species. Methods Ecol Evol, 7, 1299-1307.

Gomes, G.B., Hutson, K.S., Domingos, J.A., Villamil, S.I., Huerlimann, R., Miller, T.L. et al. (2019). Parasitic protozoan interactions with bacterial microbiome in a tropical fish farm. Aquaculture, 502, 196201.

Gómez-Zurita, J., Cardoso, A., Coronado, I., De la Cadena, G., Jurado-Rivera, J.A., Maes, J.-M. et al. (2016). High-throughput biodiversity analysis: Rapid assessment of species richness and ecological interactions of Chrysomelidae (Coleoptera) in the tropics. Zookeys, 3-26.

Graham, S.E., Chariton, A.A. \& Landis, W.G. (2019). Using Bayesian networks to predict risk to estuary water quality and patterns of benthic environmental DNA in Queensland. Integrated Environmental Assessment and Management, 15, 93-111.

Guillera-Arroita, G., Lahoz-Monfort, J.J., van Rooyen, A.R., Weeks, A.R. \& Tingley, R. (2017). Dealing with false-positive and false-negative errors about species occurrence at multiple levels. Methods Ecol Evol, 8, 1081-1091.

Günther, B., Knebelsberger, T., Neumann, H., Laakmann, S. \& Martínez Arbizu, P. (2018). Metabarcoding of marine environmental DNA based on mitochondrial and nuclear genes. Scientific Reports, 8 , 14822.

Hanfling, B., Handley, L.L., Read, D.S., Hahn, C., Li, J.L., Nichols, P. et al. (2016). Environmental DNA metabarcoding of lake fish communities reflects long-term data from established survey methods. Mol Ecol, 25, 3101-3119.

Harper, K.J., Goodwin, K.D., Harper, L.R., LaCasella, E.L., Frey, A. \& Dutton, P.H. (2020). Finding Crush: Environmental DNA Analysis as a Tool for Tracking the Green Sea Turtle Chelonia mydas in a Marine Estuary. Frontiers in Marine Science, 6.

Harper, L.R., Griffiths, N.P., Handley, L.L., Sayer, C.D., Read, D.S., Harper, K.J. et al. (2019). Development and application of environmental DNA surveillance for the threatened crucian carp (Carassius carassius). Freshwater Biol, 64, 93-107. 
Harper, L.R., Lawson Handley, L., Hahn, C., Boonham, N., Rees, H.C., Gough, K.C. et al. (2018). Needle in a haystack? A comparison of eDNA metabarcoding and targeted qPCR for detection of the great crested newt (Triturus cristatus). Ecol Evol, 8, 6330-6341.

Harrer, L.E.F. \& Levi, T. (2018). The primacy of bears as seed dispersers in salmon-bearing ecosystems. Ecosphere, 9.

Harrison, J.B., Sunday, J.M. \& Rogers, S.M. (2019). Predicting the fate of eDNA in the environment and implications for studying biodiversity. Proceedings of the Royal Society B: Biological Sciences, 286, 20191409.

Hemery, L.G., Politano, K.K. \& Henkel, S.K. (2017). Assessing differences in macrofaunal assemblages as a factor of sieve mesh size, distance between samples, and time of sampling. Environ Monit Assess, 189.

Hering, D., Borja, A., Jones, J.I., Pont, D., Boets, P., Bouchez, A. et al. (2018). Implementation options for DNA-based identification into ecological status assessment under the European Water Framework Directive. Water Research, 138, 192-205.

Hinlo, R., Furlan, E., Suitor, L. \& Gleeson, D. (2017). Environmental DNA monitoring and management of invasive fish: comparison of eDNA and fyke netting. Manag Biol Invasion, 8, 89-100.

Hobbs, J., Round, J.M., Allison, M.J. \& Helbing, C.C. (2019). Expansion of the known distribution of the coastal tailed frog, Ascaphus truei, in British Columbia, Canada, using robust eDNA detection methods. Plos One, 14.

Hopken, M.W., Orning, E.K., Young, J.K. \& Piaggio, A.J. (2016). Molecular forensics in avian conservation: a DNA-based approach for identifying mammalian predators of ground-nesting birds and eggs. BMC Research Notes, 9, 14.

Hunter, M.E., Ferrante, J.A., Meigs-Friend, G. \& Ulmer, A. (2019). Improving eDNA yield and inhibitor reduction through increased water volumes and multi-filter isolation techniques. Sci Rep-Uk, 9.

Huver, J.R., Koprivnikar, J., Johnson, P.T.J. \& Whyard, S. (2015). Development and application of an eDNA method to detect and quantify a pathogenic parasite in aquatic ecosystems. Ecol Appl, 25, 991-1002.

Itakura, H., Wakiya, R., Yamamoto, S., Kaifu, K., Sato, T. \& Minamoto, T. (2019). Environmental DNA analysis reveals the spatial distribution, abundance, and biomass of Japanese eels at the riverbasin scale. Aquat Conserv, 29, 361-373.

Jane, S.F., Wilcox, T.M., McKelvey, K.S., Young, M.K., Schwartz, M.K., Lowe, W.H. et al. (2015). Distance, flow and PCR inhibition: eDNA dynamics in two headwater streams. Mol Ecol Resour, 15, 216227.

Jerde, C.L., Chadderton, W.L., Mahon, A.R., Renshaw, M.A., Corush, J., Budny, M.L. et al. (2013). Detection of Asian carp DNA as part of a Great Lakes basin-wide surveillance program. Can J Fish Aquat Sci, 70, 522-526.

Jerde, C.L., Mahon, A.R., Chadderton, W.L. \& Lodge, D.M. (2011a). "Sight-unseen" detection of rare aquatic species using environmental DNA. Conserv Lett, 4, 150-157.

Jerde, C.L., Mahon, A.R., Chadderton, W.L. \& Lodge, D.M. (2011b). "Sight-unseen" detection of rare aquatic species using environmental DNA. Conservation Letters, 4, 150-157.

Jerde, C.L., Olds, B.P., Shogren, A.J., Andruszkiewicz, E.A., Mahon, A.R., Bolster, D. et al. (2016). Influence of Stream Bottom Substrate on Retention and Transport of Vertebrate Environmental DNA. Environ Sci Technol, 50, 8770-8779.

Jeunen, G.J., Knapp, M., Spencer, H.G., Lamare, M.D., Taylor, H.R., Stat, M. et al. (2019). Environmental DNA (eDNA) metabarcoding reveals strong discrimination among diverse marine habitats connected by water movement. Mol Ecol Resour, 19, 426-438. 
Ji, Y., Baker, C.C., Li, Y., Popescu, V.D., Wang, Z., Wang, J. et al. (2020). Large-scale Quantification of Vertebrate Biodiversity in Ailaoshan Nature Reserve from Leech iDNA. bioRxiv, 2020.2002.2010.941336.

Ji, Y., Huotari, T., Roslin, T., Martin-Schmidt, N., Wang, J., Yu, D. et al. (2019). SPIKEPIPE: A metagenomic pipeline for the accurate quantification of eukaryotic species occurrences and abundances using DNA barcodes or mitogenomes. bioRxiv, 533737.

Jia, Q., Wang, X., Zhang, Y., Cao, L. \& Fox, A.D. (2018). Drivers of waterbird communities and their declines on Yangtze River floodplain lakes. Biol Conserv, 218, 240-246.

Jo, T., Murakami, H., Masuda, R., Sakata, M.K., Yamamoto, S. \& Minamoto, T. (2017). Rapid degradation of longer DNA fragments enables the improved estimation of distribution and biomass using environmental DNA. Mol Ecol Resour, 17, e25-e33.

Judo, M.S., Wedel, A.B. \& Wilson, C. (1998). Stimulation and suppression of PCR-mediated recombination. Nucleic Acids Res, 26, 1819-1825.

Jusino, M.A., Banik, M.T., Palmer, J.M., Wray, A.K., Xiao, L., Pelton, E. et al. (2019). An improved method for utilizing high-throughput amplicon sequencing to determine the diets of insectivorous animals. Mol Ecol Resour, 19, 176-190.

Kebschull, J.M. \& Zador, A.M. (2015). Sources of PCR-induced distortions in high-throughput sequencing data sets. Nucleic Acids Res, 43.

Kemp, B.M. \& Smith, D.G. (2005). Use of bleach to eliminate contaminating DNA from the surface of bones and teeth. Forensic Sci Int, 154, 53-61.

Kessler, E.J., Ash, K.T., Barratt, S.N., Larson, E.R. \& Davis, M.A. (2020). Radiotelemetry reveals effects of upstream biomass and UV exposure on environmental DNA occupancy and detection for a large freshwater turtle. Environmental DNA, 2, 13-23.

Khelifa, R. (2019). Sensitivity of biodiversity indices to life history stage, habitat type and landscape in Odonata community. Biol Conserv, 237, 63-69.

Klein, C.J., Beher, J., Chaloupka, M., Hamann, M., Limpus, C. \& Possingham, H.P. (2017). Prioritization of Marine Turtle Management Projects: A Protocol that Accounts for Threats to Different Life History Stages. Conserv Lett, 10, 547-554.

Klymus, K.E., Richter, C.A., Chapman, D.C. \& Paukert, C. (2015). Quantification of eDNA shedding rates from invasive bighead carp Hypophthalmichthys nobilis and silver carp Hypophthalmichthys molitrix. Biol Conserv, 183, 77-84.

Knudsen, S.W., Ebert, R.B., Hesselsoe, M., Kuntke, F., Hassingboe, J., Mortensen, P.B. et al. (2019). Species-specific detection and quantification of environmental DNA from marine fishes in the Baltic Sea. J Exp Mar Biol Ecol, 510, 31-45.

Koziol, A., Stat, M., Simpson, T., Jarman, S., DiBattista, J.D., Harvey, E.S. et al. (2019). Environmental DNA metabarcoding studies are critically affected by substrate selection. Mol Ecol Resour, 19, 366376.

Kraaijeveld, K., De Weger, L.A., Garcia, M.V., Buermans, H., Frank, J., Hiemstra, P.S. et al. (2015). Efficient and sensitive identification and quantification of airborne pollen using next-generation DNA sequencing. Mol Ecol Resour, 15, 8-16.

Kuzmina, M.L., Braukmann, T.W.A. \& Zakharov, E.V. (2018). Finding the pond through the weeds: eDNA reveals underestimated diversity of pondweeds. Appl Plant Sci, 6.

Lacoursière-Roussel, A., Howland, K., Normandeau, E., Grey, E.K., Archambault, P., Deiner, K. et al. (2018). eDNA metabarcoding as a new surveillance approach for coastal Arctic biodiversity. Ecol Evol, 8, 7763-7777. 
Lacoursière-Roussel, A., Rosabal, M. \& Bernatchez, L. (2016). Estimating fish abundance and biomass from eDNA concentrations: variability among capture methods and environmental conditions. Mol Ecol Resour, 16, 1401-1414.

Lahoz-Monfort, J.J., Guillera-Arroita, G. \& Tingley, R. (2016). Statistical approaches to account for falsepositive errors in environmental DNA samples. Mol Ecol Resour, 16, 673-685.

Laramie, M.B., Pilliod, D.S. \& Goldberg, C.S. (2015). Characterizing the distribution of an endangered salmonid using environmental DNA analysis. Biol Conserv, 183, 29-37.

Laroche, O., Wood, S.A., Tremblay, L.A., Lear, G., Ellis, J.I. \& Pochon, X. (2017). Metabarcoding monitoring analysis: the pros and cons of using co-extracted environmental DNA and RNA data to assess offshore oil production impacts on benthic communities. Peerj, 5.

Lecaudey, L.A., Schletterer, M., Kuzovlev, V.V., Hahn, C. \& Weiss, S.J. (2019). Fish diversity assessment in the headwaters of the Volga River using environmental DNA metabarcoding. Aquat Conserv.

Leempoel, K., Hebert, T. \& Hadly, E.A. (2020). A comparison of eDNA to camera trapping for assessment of terrestrial mammal diversity. Proceedings of the Royal Society B: Biological Sciences, 287, 20192353.

Leray, M. \& Knowlton, N. (2017). Random sampling causes the low reproducibility of rare eukaryotic OTUs in Illumina COI metabarcoding. Peerj, 5, e3006.

Leray, M., Yang, J.Y., Meyer, C.P., Mills, S.C., Agudelo, N., Ranwez, V. et al. (2013). A new versatile primer set targeting a short fragment of the mitochondrial COI region for metabarcoding metazoan diversity: application for characterizing coral reef fish gut contents. Front Zool, 10, 34.

Levi, T., Allen, J.M., Bell, D., Joyce, J., Russell, J.R., Tallmon, D.A. et al. (2019). Environmental DNA for the enumeration and management of Pacific salmon. Molecular Ecology Resources, 19, 597-608.

Levy-Booth, D.J., Campbell, R.G., Gulden, R.H., Hart, M.M., Powell, J.R., Klironomos, J.N. et al. (2007). Cycling of extracellular DNA in the soil environment. Soil Biol Biochem, 39, 2977-2991.

Liang, Z. \& Keeley, A. (2013a). Filtration Recovery of Extracellular DNA from Environmental Water Samples. Environmental Science \& Technology, 47, 9324-9331.

Liang, Z.B. \& Keeley, A. (2013b). Filtration Recovery of Extracellular DNA from Environmental Water Samples. Environ Sci Technol, 47, 9324-9331.

Lim, N.K.M., Tay, Y.C., Srivathsan, A., Tan, J.W.T., Kwik, J.T.B., Baloglu, B. et al. (2016). Next-generation freshwater bioassessment: eDNA metabarcoding with a conserved metazoan primer reveals species-rich and reservoir-specific communities. Roy Soc Open Sci, 3.

Lin, M.X., Zhang, S. \& Yao, M. (2019). Effective detection of environmental DNA from the invasive American bullfrog. Biol Invasions, 21, 2255-2268.

Lindahl, T. (1993). Instability and Decay of the Primary Structure of DNA. Nature, 362, 709-715.

Liu, S., Zhou, X., Zhou, C. \& Yang, C. (2017). Filling reference gaps via assembling DNA barcodes using high-throughput sequencing-moving toward barcoding the world. Gigascience, 6.

Lugg, W.H., Griffiths, J., van Rooyen, A.R., Weeks, A.R. \& Tingley, R. (2018). Optimal survey designs for environmental DNA sampling. Methods in Ecology and Evolution, 9, 1049-1059.

Ma, H.J., Stewart, K., Lougheed, S., Zheng, J.S., Wang, Y.X. \& Zhao, J.F. (2016). Characterization, optimization, and validation of environmental DNA (eDNA) markers to detect an endangered aquatic mammal. Conserv Genet Resour, 8, 561-568.

Machida, R.J., Leray, M., Ho, S.L. \& Knowlton, N. (2017). Metazoan mitochondrial gene sequence reference datasets for taxonomic assignment of environmental samples. Sci Data, 4, 170027.

Mahe, F., Rognes, T., Quince, C., de Vargas, C. \& Dunthorn, M. (2014). Swarm: robust and fast clustering method for amplicon-based studies. Peerj, 2.

Mahe, F., Rognes, T., Quince, C., de Vargas, C. \& Dunthorn, M. (2015). Swarm v2: highly-scalable and high-resolution amplicon clustering. Peerj, 3. 
Mahon, A.R., Jerde, C.L., Galaska, M., Bergner, J.L., Chadderton, W.L., Lodge, D.M. et al. (2013). Validation of eDNA Surveillance Sensitivity for Detection of Asian Carps in Controlled and Field Experiments. Plos One, 8.

Majaneva, M., Diserud, O.H., Eagle, S.H.C., Boström, E., Hajibabaei, M. \& Ekrem, T. (2018). Environmental DNA filtration techniques affect recovered biodiversity. Scientific Reports, 8, 4682.

Manfrin, C., Souty-Grosset, C., Anastacio, P.M., Reynolds, J. \& Giulianini, P.G. (2019). Detection and Control of Invasive Freshwater Crayfish: From Traditional to Innovative Methods. Diversity-Basel, 11.

Marshall, N.T. \& Stepien, C.A. (2019). Invasion genetics from eDNA and thousands of larvae: A targeted metabarcoding assay that distinguishes species and population variation of zebra and quagga mussels. Ecol Evol, 9, 3515-3538.

Maruyama, A., Nakamura, K., Yamanaka, H., Kondoh, M. \& Minamoto, T. (2014). The Release Rate of Environmental DNA from Juvenile and Adult Fish. PLOS ONE, 9, e114639.

Maruyama, A., Nakamura, K., Yamanaka, H., Kondoh, M. \& Minamoto, T. (2019). The Release Rate of Environmental DNA from Juvenile and Adult Fish (vol 9, e114639, 2014). Plos One, 14.

Maruyama, A., Sugatani, K., Watanabe, K., Yamanaka, H. \& Imamura, A. (2018). Environmental DNA analysis as a non-invasive quantitative tool for reproductive migration of a threatened endemic fish in rivers. Ecol Evol, 8, 11964-11974.

Mata, V.A., Amorim, F., Corley, M.F.V., McCracken, G.F., Rebelo, H. \& Beja, P. (2016). Female dietary bias towards large migratory moths in the European free-tailed bat (Tadarida teniotis). Biol Letters, 12.

Mata, V.A., Rebelo, H., Amorim, F., McCracken, G.F., Jarman, S. \& Beja, P. (2019). How much is enough? Effects of technical and biological replication on metabarcoding dietary analysis. Mol Ecol, 28, 165-175.

Matter, A.N., Falke, J.A., Lopez, J.A. \& Savereide, J.W. (2018). A Rapid-Assessment Method to Estimate the Distribution of Juvenile Chinook Salmon in Tributary Habitats Using eDNA and Occupancy Estimation. N Am J Fish Manage, 38, 223-236.

Minamoto, T., Uchii, K., Takahara, T., Kitayoshi, T., Tsuji, S., Yamanaka, H. et al. (2017). Nuclear internal transcribed spacer-1 as a sensitive genetic marker for environmental DNA studies in common carp Cyprinus carpio. Mol Ecol Resour, 17, 324-333.

Minamoto, T., Yamanaka, H., Takahara, T., Honjo, M.N. \& Kawabata, Z. (2012). Surveillance of fish species composition using environmental DNA. Limnology, 13, 193-197.

Montagna, M., Berruti, A., Bianciotto, V., Cremonesi, P., Giannico, R., Gusmeroli, F. et al. (2018). Differential biodiversity responses between kingdoms (plants, fungi, bacteria and metazoa) along an Alpine succession gradient. Mol Ecol, 27, 3671-3685.

Mora, A.J., Prosse, S.W.J. \& Mora, J.A. (2019). DNA metabarcoding allows non-invasive identification of arthropod prey provisioned to nestling Rufous hummingbirds (Selasphorus rufus). Peerj, 7.

Moraes, C.T. (2001). What regulates mitochondrial DNA copy number in animal cells? Trends Genet, 17, 199-205.

Morin, P.A., Chambers, K.E., Boesch, C. \& Vigilant, L. (2001). Quantitative polymerase chain reaction analysis of DNA from noninvasive samples for accurate microsatellite genotyping of wild chimpanzees (Pan troglodytes verus). Mol Ecol, 10, 1835-1844.

Morley, S.A. \& Nielsen, B.L. (2016). Chloroplast DNA Copy Number Changes during Plant Development in Organelle DNA Polymerase Mutants. Front Plant Sci, 7. 
Moushomi, R., Wilgar, G., Carvalho, G., Creer, S. \& Seymour, M. (2019). Environmental DNA size sorting and degradation experiment indicates the state of Daphnia magna mitochondrial and nuclear eDNA is subcellular. Scientific Reports, 9, 12500.

Moyer, G.R., Diaz-Ferguson, E., Hill, J.E. \& Shea, C. (2014). Assessing Environmental DNA Detection in Controlled Lentic Systems. Plos One, 9.

Muha, T.P., Robinson, C.V., Garcia de Leaniz, C. \& Consuegra, S. (2019). An optimised eDNA protocol for detecting fish in lentic and lotic freshwaters using a small water volume. PLOS ONE, 14, e0219218.

Murakami, H., Yoon, S., Kasai, A., Minamoto, T., Yamamoto, S., Sakata, M.K. et al. (2019). Dispersion and degradation of environmental DNA from caged fish in a marine environment. Fisheries Sci, 85, 327-337.

Nardi, C.F., Fernandez, D.A., Vanella, F.A. \& Chalde, T. (2019). The expansion of exotic Chinook salmon (Oncorhynchus tshawytscha) in the extreme south of Patagonia: an environmental DNA approach. Biol Invasions, 21, 1415-1425.

Nichols, R.V., Vollmers, C., Newsom, L.A., Wang, Y., Heintzman, P.D., Leighton, M. et al. (2018). Minimizing polymerase biases in metabarcoding. Mol Ecol Resour, 18, 927-939.

O'Donnell, J.L., Kelly, R.P., Shelton, A.O., Samhouri, J.F., Lowell, N.C. \& Williams, G.D. (2017). Spatial distribution of environmental DNA in a nearshore marine habitat. Peerj, 5.

O’Donnell, J.L., Kelly, R.P., Lowell, N.C. \& Port, J.A. (2016). Indexed PCR Primers Induce Template-Specific Bias in Large-Scale DNA Sequencing Studies. PLOS ONE, 11, e0148698.

O’Donnell, J.L., Kelly, R.P., Shelton, A.O., Samhouri, J.F., Lowell, N.C. \& Williams, G.D. (2017). Spatial distribution of environmental DNA in a nearshore marine habitat. Peerj, 5, e3044.

Olds, B.P., Jerde, C.L., Renshaw, M.A., Li, Y.Y., Evans, N.T., Turner, C.R. et al. (2016). Estimating species richness using environmental DNA. Ecol Evol, 6, 4214-4226.

Olson, Z.H., Briggler, J.T. \& Williams, R.N. (2012a). An eDNA approach to detect eastern hellbenders ( $<$ i>Cryptobranchus a. alleganiensis</i>) using samples of water. Wildlife Research, 39, 629-636, 628.

Olson, Z.H., Briggler, J.T. \& Williams, R.N. (2012b). An eDNA approach to detect eastern hellbenders (Cryptobranchus a. alleganiensis) using samples of water. Wildlife Res, 39, 629-636.

Orzechowski, S.C.M., Frederick, P.C., Dorazio, R.M. \& Hunter, M.E. (2019). Environmental DNA sampling reveals high occupancy rates of invasive Burmese pythons at wading bird breeding aggregations in the central Everglades. Plos One, 14.

Outhwaite, C.L., Gregory, R.D., Chandler, R.E., Collen, B. \& Isaac, N.J.B. (2020). Complex long-term biodiversity change among invertebrates, bryophytes and lichens. Nature Ecology \& Evolution, 4, 384-392.

Ovaskainen, O., Moliterno de Camargo, U. \& Somervuo, P. (2018). Animal Sound Identifier (ASI): software for automated identification of vocal animals. Ecol Lett, 21, 1244-1254.

Piaggio, A.J., Engeman, R.M., Hopken, M.W., Humphrey, J.S., Keacher, K.L., Bruce, W.E. et al. (2014). Detecting an elusive invasive species: a diagnostic PCR to detect Burmese python in Florida waters and an assessment of persistence of environmental DNA. Mol Ecol Resour, 14, 374-380.

Piggott, M.P. (2016). Evaluating the effects of laboratory protocols on eDNA detection probability for an endangered freshwater fish. Ecol Evol, 6, 2739-2750.

Pilliod, D.S., Goldberg, C.S., Arkle, R.S. \& Waits, L.P. (2013). Estimating occupancy and abundance of stream amphibians using environmental DNA from filtered water samples. Can J Fish Aquat Sci, 70, 1123-1130.

Pilliod, D.S., Goldberg, C.S., Arkle, R.S. \& Waits, L.P. (2014). Factors influencing detection of eDNA from a stream-dwelling amphibian. Mol Ecol Resour, 14, 109-116. 
Piñol, J., Senar, M.A. \& Symondson, W.O.C. (2019). The choice of universal primers and the characteristics of the species mixture determine when DNA metabarcoding can be quantitative. Mol Ecol, 28, 407-419.

Pompanon, F., Deagle, B.E., Symondson, W.O.C., Brown, D.S., Jarman, S.N. \& Taberlet, P. (2012). Who is eating what: diet assessment using next generation sequencing. Mol Ecol, 21, 1931-1950.

Porter, T.M. \& Hajibabaei, M. (2018). Over 2.5 million COI sequences in GenBank and growing. PLOS ONE, 13, e0200177.

Preissler, K., Watzal, A.D., Vences, M. \& Steinfartz, S. (2019). Detection of elusive fire salamander larvae (Salamandra salamandra) in streams via environmental DNA. Amphibia-Reptilia, 40, 55-64.

Prince, A.M. \& Andrus, L. (1992). Pcr - How to Kill Unwanted DNA. Biotechniques, 12, 358-\&.

Qu, C. \& Stewart, K.A. (2019a). Evaluating monitoring options for conservation: comparing traditional and environmental DNA tools for a critically endangered mammal. The Science of Nature, 106, 9.

Qu, C. \& Stewart, K.A. (2019b). Evaluating monitoring options for conservation: comparing traditional and environmental DNA tools for a critically endangered mammal. Sci Nat-Heidelberg, 106.

Radstrom, P., Knutsson, R., Wolffs, P., Lovenklev, M. \& Lofstrom, C. (2004). Pre-PCR processing Strategies to generate PCR-compatible samples. Mol Biotechnol, 26, 133-146.

Rajan, S.C., Athira, K., Jaishanker, R., Sooraj, N.P. \& Sarojkumar, V. (2019). Rapid assessment of biodiversity using acoustic indices. Biodivers Conserv, 28, 2371-2383.

Ratnasingham, S. \& Hebert, P.D. (2007). bold: The Barcode of Life Data System (http://www.barcodinglife.org). Mol Ecol Notes, 7, 355-364.

Rees, H.C., Baker, C.A., Gardner, D.S., Maddison, B.C. \& Gough, K.C. (2017). The detection of great crested newts year round via environmental DNA analysis. BMC Research Notes, 10, 327.

Reinhardt, T., van Schingen, M., Windisch, H.S., Nguyen, T.Q., Ziegler, T. \& Fink, P. (2019). Monitoring a loss: Detection of the semi-aquatic crocodile lizard (Shinisaurus crocodilurus) in inaccessible habitats via environmental DNA. Aquat Conserv, 29, 353-360.

Renshaw, M.A., Olds, B.P., Jerde, C.L., McVeigh, M.M. \& Lodge, D.M. (2015a). The room temperature preservation of filtered environmental DNA samples and assimilation into a phenol-chloroformisoamyl alcohol DNA extraction. Mol Ecol Resour, 15, 168-176.

Renshaw, M.A., Olds, B.P., Jerde, C.L., McVeigh, M.M. \& Lodge, D.M. (2015b). The room temperature preservation of filtered environmental DNA samples and assimilation into a phenol-chloroformisoamyl alcohol DNA extraction. Molecular Ecology Resources, 15, 168-176.

Rice, C.J., Larson, E.R. \& Taylor, C.A. (2018). Environmental DNA detects a rare large river crayfish but with little relation to local abundance. Freshwater Biol, 63, 443-455.

Riggio, J., Kija, H., Masenga, E., Mbwilo, F., Van de Perre, F. \& Caro, T. (2018). Sensitivity of Africa's larger mammals to humans. J Nat Conserv, 43, 136-145.

Rivera, S.F., Vasselon, V., Bouchez, A. \& Rimet, F. (2020). Diatom metabarcoding applied to large scale monitoring networks: Optimization of bioinformatics strategies using Mothur software. Ecol Indic, 109, 105775.

Rodriguez-Estrella, R., Estrada, C.G., Alvarez-Castaneda, S.T. \& Ferrer-Sanchez, Y. (2019). Comparing individual raptor species and coarse taxonomic groups as biodiversity surrogates in desert ecosystems. Biodivers Conserv, 28, 1225-1244.

Rose, J.P., Wademan, C., Weir, S., Wood, J.S. \& Todd, B.D. (2019). Traditional trapping methods outperform eDNA sampling for introduced semi-aquatic snakes. Plos One, 14.

Roussel, J.-M., Paillisson, J.-M., Tréguier, A. \& Petit, E. (2015). The downside of eDNA as a survey tool in water bodies. Journal of Applied Ecology, 52, 823-826.

Rudko, S.P., Turnbull, A., Reimink, R.L., Froelich, K. \& Hanington, P.C. (2019). Species-specific qPCR assays allow for high-resolution population assessment of four species avian schistosome that 
cause swimmer's itch in recreational lakes. International journal for parasitology. Parasites and wildlife, 9, 122-129.

Rytkonen, S., Vesterinen, E.J., Westerduin, C., Leviakangas, T., Vatka, E., Mutanen, M. et al. (2019). From feces to data: A metabarcoding method for analyzing consumed and available prey in a birdinsect food web. Ecol Evol, 9, 631-639.

Saha, A., McRae, L., Dodd, C.K., Gadsden, H., Hare, K.M., Lukoschek, V. et al. (2018). Tracking Global Population Trends: Population Time-Series Data and a Living Planet Index for Reptiles. J Herpetol, 52, 259-268.

Sales, N.G., Wangensteen, O.S., Carvalho, D.C., Deiner, K., Præbel, K., Coscia, I. et al. (2020). Space-time dynamics in monitoring neotropical fish communities using eDNA metabarcoding. bioRxiv, 2020.2002.2004.933366.

Sansom, B.J. \& Sassoubre, L.M. (2017). Environmental DNA (eDNA) Shedding and Decay Rates to Model Freshwater Mussel eDNA Transport in a River. Environ Sci Technol, 51, 14244-14253.

Sassoubre, L.M., Yamahara, K.M., Gardner, L.D., Block, B.A. \& Boehm, A.B. (2016). Quantification of Environmental DNA (eDNA) Shedding and Decay Rates for Three Marine Fish. Environ Sci Technol, 50, 10456-10464.

Sawaya, N.A., Djurhuus, A., Closek, C.J., Hepner, M., Olesin, E., Visser, L. et al. (2019). Assessing eukaryotic biodiversity in the Florida Keys National Marine Sanctuary through environmental DNA metabarcoding. Ecol Evol, 9, 1029-1040.

Schmidt, B.R., Kery, M., Ursenbacher, S., Hyman, O.J. \& Collins, J.P. (2013). Site occupancy models in the analysis of environmental DNA presence/absence surveys: a case study of an emerging amphibian pathogen. Methods Ecol Evol, 4, 646-653.

Schrader, C., Schielke, A., Ellerbroek, L. \& Johne, R. (2012). PCR inhibitors - occurrence, properties and removal. J Appl Microbiol, 113, 1014-1026.

Schumer, G., Crowley, K., Maltz, E., Johnston, M., Anders, P. \& Blankenship, S. (2019). Utilizing environmental DNA for fish eradication effectiveness monitoring in streams. Biol Invasions, 21, 3415-3426.

Sekercioglu, C.H., Mendenhall, C.D., Oviedo-Brenes, F., Horns, J.J., Ehrlich, P.R. \& Daily, G.C. (2019). Long-term declines in bird populations in tropical agricultural countryside. P Natl Acad Sci USA, 116, 9903-9912.

Sengupta, M.E., Hellstrom, M., Kariuki, H.C., Olsen, A., Thomsen, P.F., Mejer, H. et al. (2019). Environmental DNA for improved detection and environmental surveillance of schistosomiasis. $P$ Natl Acad Sci USA, 116, 8931-8940.

Seymour, M. (2019). Rapid progression and future of environmental DNA research. Communications Biology, 2, 80.

Seymour, M., Durance, I., Cosby, B.J., Ransom-Jones, E., Deiner, K., Ormerod, S.J. et al. (2018). Acidity promotes degradation of multi-species environmental DNA in lotic mesocosms. Communications Biology, 1, 4.

Shelton, A.O., Kelly, R.P., O'Donnell, J.L., Park, L., Schwenke, P., Greene, C. et al. (2019). Environmental DNA provides quantitative estimates of a threatened salmon species. Biol Conserv, 237, 383-391.

Sigsgaard, E.E., Carl, H., Moller, P.R. \& Thomsen, P.F. (2015a). Monitoring the near-extinct European weather loach in Denmark based on environmental DNA from water samples. Biological Conservation, 183, 46-52.

Sigsgaard, E.E., Carl, H., Møller, P.R. \& Thomsen, P.F. (2015b). Monitoring the near-extinct European weather loach in Denmark based on environmental DNA from water samples. Biological Conservation, 183, 46-52. 
Singer, D., Kosakyan, A., Seppey, C.V.W., Pillonel, A., Fernández, L.D., Fontaneto, D. et al. (2018). Environmental filtering and phylogenetic clustering correlate with the distribution patterns of cryptic protist species. Ecology, 99, 904-914.

Singer, G.A.C., Fahner, N.A., Barnes, J.G., McCarthy, A. \& Hajibabaei, M. (2019). Comprehensive biodiversity analysis via ultra-deep patterned flow cell technology: a case study of eDNA metabarcoding seawater. Scientific Reports, 9, 5991.

Sirois, S.H. \& Buckley, D.H. (2019). Factors governing extracellular DNA degradation dynamics in soil. Environmental Microbiology Reports, 11, 173-184.

Smart, A.S., Weeks, A.R., van Rooyen, A.R., Moore, A., McCarthy, M.A. \& Tingley, R. (2016). Assessing the cost-efficiency of environmental DNA sampling. Methods Ecol Evol, 7, 1291-1298.

Song, J.W., Small, M.J. \& Casman, E.A. (2017). Making sense of the noise: The effect of hydrology on silver carp eDNA detection in the Chicago area waterway system. Sci Total Environ, 605, 713-720.

Spear, S.F., Groves, J.D., Williams, L.A. \& Waits, L.P. (2015). Using environmental DNA methods to improve detectability in a hellbender (Cryptobranchus alleganiensis) monitoring program. Biol Conserv, 183, 38-45.

Spens, J., Evans, A.R., Halfmaerten, D., Knudsen, S.W., Sengupta, M.E., Mak, S.S.T. et al. (2017). Comparison of capture and storage methods for aqueous macrobial eDNA using an optimized extraction protocol: advantage of enclosed filter. Methods in Ecology and Evolution, 8, 635-645.

Srinivasan, U. (2019). Morphological and Behavioral Correlates of Long-Term Bird Survival in Selectively Logged Forest. Frontiers in Ecology and Evolution, 7.

Stadhouders, R., Pas, S.D., Anber, J., Voermans, J., Mes, T.H.M. \& Schutten, M. (2010). The effect of primer-template mismatches on the detection and quantification of nucleic acids using the $5^{\prime}$ nuclease assay. J Mol Diagn, 12, 109-117.

Steenweg, R., Hebblewhite, M., Kays, R., Ahumada, J., Fisher, J.T., Burton, C. et al. (2017). Scaling-up camera traps: monitoring the planet's biodiversity with networks of remote sensors. Front Ecol Environ, 15, 26-34.

Stewart, K., Ma, H.J., Zheng, J.S. \& Zhao, J.F. (2017). Using environmental DNA to assess population-wide spatiotemporal reserve use. Conserv Biol, 31, 1173-1182.

Stewart, K.A. (2019). Understanding the effects of biotic and abiotic factors on sources of aquatic environmental DNA. Biodiversity and Conservation, 28, 983-1001.

Stoeckle, B.C., Kuehn, R. \& Geist, J. (2016). Environmental DNA as a monitoring tool for the endangered freshwater pearl mussel (Margaritifera margaritifera L.): a substitute for classical monitoring approaches? Aquat Conserv, 26, 1120-1129.

Stoeckle, M.Y., Soboleva, L. \& Charlop-Powers, Z. (2017). Aquatic environmental DNA detects seasonal fish abundance and habitat preference in an urban estuary. Plos One, 12.

Strickland, G.J. \& Roberts, J.H. (2019). Utility of eDNA and occupancy models for monitoring an endangered fish across diverse riverine habitats. Hydrobiologia, 826, 129-144.

Strickler, K.M., Fremier, A.K. \& Goldberg, C.S. (2015). Quantifying effects of UV-B, temperature, and pH on eDNA degradation in aquatic microcosms. Biological Conservation, 183, 85-92.

Sutter, M. \& Kinziger, A.P. (2019). Rangewide tidewater goby occupancy survey using environmental DNA. Conserv Genet, 20, 597-613.

TABERLET, P., COISSAC, E., HAJIBABAEI, M. \& RIESEBERG, L.H. (2012a). Environmental DNA. Mol Ecol, 21, 1789-1793.

Taberlet, P., Prud'homme, S.M., Campione, E., Roy, J., Miquel, C., Shehzad, W. et al. (2012b). Soil sampling and isolation of extracellular DNA from large amount of starting material suitable for metabarcoding studies. Mol Ecol, 21, 1816-1820. 
Takahara, T., Iwai, N., Yasumiba, K. \& Igawa, T. Comparison of the detection of 3 endangered frog species by eDNA and acoustic surveys across 3 seasons. Freshwater Science, 0, 000-000.

Takahara, T., Iwai, N., Yasumiba, K. \& Igawa, T. (2020). Comparison of the detection of 3 endangered frog species by eDNA and acoustic surveys across 3 seasons. Freshw Sci, 39, 18-27.

Takahara, T., Minamoto, T., Yamanaka, H., Doi, H. \& Kawabata, Z. (2012). Estimation of Fish Biomass Using Environmental DNA. Plos One, 7.

Takeuchi, A., lijima, T., Kakuzen, W., Watanabe, S., Yamada, Y., Okamura, A. et al. (2019a). Release of eDNA by different life history stages and during spawning activities of laboratory-reared Japanese eels for interpretation of oceanic survey data. Scientific Reports, 9, 6074.

Takeuchi, A., lijima, T., Kakuzen, W., Watanabe, S., Yamada, Y., Okamura, A. et al. (2019b). Release of eDNA by different life history stages and during spawning activities of laboratory-reared Japanese eels for interpretation of oceanic survey data. Sci Rep-Uk, 9.

Takeuchi, A., Watanabe, S., Yamamoto, S., Miller, M.J., Fukuba, T., Miwa, T. et al. (2019c). First use of oceanic environmental DNA to study the spawning ecology of the Japanese eel Anguilla japonica. Mar Ecol Prog Ser, 609, 187-196.

Thomas, A.C., Howard, J., Nguyen, P.L., Seimon, T.A. \& Goldberg, C.S. (2018). ANDe (TM): A fully integrated environmental DNA sampling system. Methods Ecol Evol, 9, 1379-1385.

Thomas, A.C., Nguyen, P.L., Howard, J. \& Goldberg, C.S. (2019). A self-preserving, partially biodegradable eDNA filter. Methods in Ecology and Evolution, 10, 1136-1141.

Thomsen, P.F., Kielgast, J., Iversen, L.L., Moller, P.R., Rasmussen, M. \& Willerslev, E. (2012a). Detection of a Diverse Marine Fish Fauna Using Environmental DNA from Seawater Samples. Plos One, 7.

Thomsen, P.F., Kielgast, J., Iversen, L.L., Møller, P.R., Rasmussen, M. \& Willerslev, E. (2012b). Detection of a Diverse Marine Fish Fauna Using Environmental DNA from Seawater Samples. PLOS ONE, 7, e41732.

Thomsen, P.F., Kielgast, J., Iversen, L.L., Wiuf, C., Rasmussen, M., Gilbert, M.T.P. et al. (2012c). Monitoring endangered freshwater biodiversity using environmental DNA. Molecular Ecology, 21, 2565-2573.

Thomsen, P.F. \& Sigsgaard, E.E. (2019). Environmental DNA metabarcoding of wild flowers reveals diverse communities of terrestrial arthropods. Ecol Evol, 9, 1665-1679.

Thomsen, P.F. \& Willerslev, E. (2015). Environmental DNA - An emerging tool in conservation for monitoring past and present biodiversity. Biol Conserv, 183, 4-18.

Tillotson, M.D., Kelly, R.P., Duda, J.J., Hoy, M., Kralj, J. \& Quinn, T.P. (2018). Concentrations of environmental DNA (eDNA) reflect spawning salmon abundance at fine spatial and temporal scales. Biol Conserv, 220, 1-11.

Tingley, R., Greenlees, M., Oertel, S., van Rooyen, A.R. \& Weeks, A.R. (2019). Environmental DNA sampling as a surveillance tool for cane toad Rhinella marina introductions on offshore islands. Biol Invasions, 21, 1-6.

Togaki, D., Doi, H. \& Katano, I. (2020). Detection of freshwater mussels (Sinanodonta spp.) in artificial ponds through environmental DNA: a comparison with traditional hand collection methods. Limnology, 21, 59-65.

Trebitz, A.S., Hoffman, J.C., Darling, J.A., Pilgrim, E.M., Kelly, J.R., Brown, E.A. et al. (2017). Early detection monitoring for aquatic non-indigenous species: Optimizing surveillance, incorporating advanced technologies, and identifying research needs. J Environ Manage, 202, 299-310.

Tsuji, S., Ushio, M., Sakurai, S., Minamoto, T. \& Yamanaka, H. (2017). Water temperature-dependent degradation of environmental DNA and its relation to bacterial abundance. PLOS ONE, 12, e0176608. 
Tsukamoto, K., Chow, S., Otake, T., Kurogi, H., Mochioka, N., Miller, M.J. et al. (2011). Oceanic spawning ecology of freshwater eels in the western North Pacific. Nat Commun, 2, 179.

Turner, C.R., Barnes, M.A., Xu, C.C.Y., Jones, S.E., Jerde, C.L. \& Lodge, D.M. (2014a). Particle size distribution and optimal capture of aqueous macrobial eDNA. Methods Ecol Evol, 5, 676-684.

Turner, C.R., Miller, D.J., Coyne, K.J. \& Corush, J. (2014b). Improved Methods for Capture, Extraction, and Quantitative Assay of Environmental DNA from Asian Bigheaded Carp (Hypophthalmichthys spp.). Plos One, 9.

Turner, C.R., Uy, K.L. \& Everhart, R.C. (2015). Fish environmental DNA is more concentrated in aquatic sediments than surface water. Biol Conserv, 183, 93-102.

Ulibarri, R.M., Bonar, S.A., Rees, C., Amberg, J., Ladell, B. \& Jackson, C. (2017). Comparing Efficiency of American Fisheries Society Standard Snorkeling Techniques to Environmental DNA Sampling Techniques. N Am J Fish Manage, 37, 644-651.

Unnithan, V.V., Unc, A., Joe, V. \& Smith, G.B. (2014). Short RNA indicator sequences are not completely degraded by autoclaving. Scientific reports, 4, 4070-4070.

Valentini, A., Taberlet, P., Miaud, C., Civade, R., Herder, J., Thomsen, P.F. et al. (2016a). Next-generation monitoring of aquatic biodiversity using environmental DNA metabarcoding. Mol Ecol, 25, 929942.

Valentini, A., Taberlet, P., Miaud, C., Civade, R., Herder, J., Thomsen, P.F. et al. (2016b). Next-generation monitoring of aquatic biodiversity using environmental DNA metabarcoding. Mol Ecol, 25, 929942.

van der Heyde, M., Bunce, M., Wardell-Johnson, G., Fernandes, K., White, N.E. \& Nevill, P. Testing multiple substrates for terrestrial biodiversity monitoring using environmental DNA (eDNA) metabarcoding. Mol Ecol Resour, n/a.

van der Heyde, M., Bunce, M., Wardell-Johnson, G., Fernandes, K., White, N.E. \& Nevill, P. Testing multiple substrates for terrestrial biodiversity monitoring using environmental DNA metabarcoding. Mol Ecol Resour, n/a.

Vimercati, G., Labadesse, M., Dejean, T. \& Secondi, J. (2020). Assessing the effect of landscape features on pond colonisation by an elusive amphibian invader using environmental DNA. Freshwater Biol, 65, 502-513.

Voros, J., Marton, O., Schmidt, B.R., Gal, J.T. \& Jelic, D. (2017). Surveying Europe's Only Cave-Dwelling Chordate Species (Proteus anguinus) Using Environmental DNA. Plos One, 12.

Walsh, J.R., Spear, M.J., Shannon, T.P., Krysan, P.J. \& Vander Zanden, M.J. (2019). Using eDNA, sediment subfossils, and zooplankton nets to detect invasive spiny water flea (Bythotrephes longimanus). Biol Invasions, 21, 377-389.

Watson, R.J. \& Blackwell, B. (2000). Purification and characterization of a common soil component which inhibits the polymerase chain reaction. Can J Microbiol, 46, 633-642.

Wei, N., Nakajima, F. \& Tobino, T. (2018). Effects of treated sample weight and DNA marker length on sediment eDNA based detection of a benthic invertebrate. Ecol Indic, 93, 267-273.

Weltz, K., Lyle, J.M., Ovenden, J., Morgan, J.A.T., Moreno, D.A. \& Semmens, J.M. (2017). Application of environmental DNA to detect an endangered marine skate species in the wild. Plos One, 12.

Wilcox, T.M., McKelvey, K.S., Young, M.K., Jane, S.F., Lowe, W.H., Whiteley, A.R. et al. (2013). Robust detection of rare species using environmental DNA: the importance of primer specificity. Plos One, 8, e59520-e59520.

Wilcox, T.M., McKelvey, K.S., Young, M.K., Sepulveda, A.J., Shepard, B.B., Jane, S.F. et al. (2016). Understanding environmental DNA detection probabilities: A case study using a stream-dwelling char Salvelinus fontinalis. Biol Conserv, 194, 209-216. 
Wilcox, T.M., Zarn, K.E., Piggott, M.P., Young, M.K., McKelvey, K.S. \& Schwartz, M.K. (2018). Capture enrichment of aquatic environmental DNA: A first proof of concept. Mol Ecol Resour, 18, 13921401.

Williams, K.E., Huyvaert, K.P. \& Piaggio, A.J. (2016). No filters, no fridges: a method for preservation of water samples for eDNA analysis. BMC Research Notes, 9, 298.

Willoughby, J.R., Wijayawardena, B.K., Sundaram, M., Swihart, R.K. \& Dewoody, J.A. (2016). The importance of including imperfect detection models in eDNA experimental design. Mol Ecol Resour, 16, 837-844.

Wilson, C.C., Wozney, K.M. \& Smith, C.M. (2016). Recognizing false positives: synthetic oligonucleotide controls for environmental DNA surveillance. Methods Ecol Evol, 7, 23-29.

Wineland, S.M., Welch, S.M., Pauley, T.K., Apodaca, J.J., Olszack, M., Mosher, J.J. et al. (2019). Using environmental DNA and occupancy modelling to identify drivers of eastern hellbender (Cryptobranchus alleganiensis alleganiensis) extirpation. Freshwater Biol, 64, 208-221.

Wood, S.A., Pochon, X., Ming, W., von Ammon, U., Woods, C., Carter, M. et al. (2019). Considerations for incorporating real-time PCR assays into routine marine biosecurity surveillance programmes: a case study targeting the Mediterranean fanworm (Sabella spallanzanii) and club tunicate (Styela clava). Genome, 62, 137-146.

Wu, Q.Q., Kawano, K., Uehara, Y., Okuda, N., Hongo, M., Tsuji, S. et al. (2018). Environmental DNA reveals nonmigratory individuals of Palaemon paucidens overwintering in Lake Biwa shallow waters. Freshw Sci, 37, 307-314.

Xia, Z.Q., Zhan, A.B., Gao, Y.C., Zhang, L., Haffner, G.D. \& Maclsaac, H.J. (2018). Early detection of a highly invasive bivalve based on environmental DNA (eDNA). Biol Invasions, 20, 437-447.

Xiong, W. \& Zhan, A.B. (2018). Testing clustering strategies for metabarcoding-based investigation of community-environment interactions. Mol Ecol Resour, 18, 1326-1338.

Yamahara, K.M., Preston, C.M., Birch, J., Walz, K., Marin, R., Jensen, S. et al. (2019). In situ Autonomous Acquisition and Preservation of Marine Environmental DNA Using an Autonomous Underwater Vehicle. Frontiers in Marine Science, 6.

Yamamoto, S., Masuda, R., Sato, Y., Sado, T., Araki, H., Kondoh, M. et al. (2017). Environmental DNA metabarcoding reveals local fish communities in a species-rich coastal sea. Sci Rep-Uk, 7.

Yamanaka, H., Minamoto, T., Matsuura, J., Sakurai, S., Tsuji, S., Motozawa, H. et al. (2017). A simple method for preserving environmental DNA in water samples at ambient temperature by addition of cationic surfactant. Limnology, 18, 233-241.

Yang, J. \& Zhang, X. (2020). eDNA metabarcoding in zooplankton improves the ecological status assessment of aquatic ecosystems. Environment International, 134, 105230.

Yoccoz, N.G., Brathen, K.A., Gielly, L., Haile, J., Edwards, M.E., Goslar, T. et al. (2012). DNA from soil mirrors plant taxonomic and growth form diversity. Mol Ecol, 21, 3647-3655.

Young, M.R., Proctor, H.C., deWaard, J.R. \& Hebert, P.D.N. DNA Barcodes Expose Unexpected Diversity in Canadian Mites. Mol Ecol, 0.

Zeale, M.R.K., Butlin, R.K., Barker, G.L.A., Lees, D.C. \& Jones, G. (2011). Taxon-specific PCR for DNA barcoding arthropod prey in bat faeces. Mol Ecol Resour, 11, 236-244.

Zhang, S., Lu, Q., Wang, Y., Wang, X., Zhao, J. \& Yao, M. (2020a). Assessment of fish communities using environmental DNA: Effect of spatial sampling design in lentic systems of different sizes. Mol Ecol Resour, 20, 242-255.

Zhang, Y., Pavlovska, M., Stoica, E., Prekrasna, I., Yang, J., Slobodnik, J. et al. (2020b). Holistic pelagic biodiversity monitoring of the Black Sea via eDNA metabarcoding approach: From bacteria to marine mammals. Environment International, 135, 105307. 
1529

1530

1531

1532

1533

1534
Zhou, X., Li, Y., Liu, S., Yang, Q., Su, X., Zhou, L. et al. (2013). Ultra-deep sequencing enables high-fidelity recovery of biodiversity for bulk arthropod samples without PCR amplification. Gigascience, 2, 4.

Zinger, L., Taberlet, P., Schimann, H., Bonin, A., Boyer, F., De Barba, M. et al. (2019). Body size determines soil community assembly in a tropical forest. Mol Ecol, 28, 528-543. 